\title{
ANALYSIS OF AQUIFER TESTS CONDUCTED IN BOREHOLE USW G-2, 1996, YUCCA MOUNTAIN, NEVADA
}

\section{U.S. GEOLOGICAL SURVEY}

Water-Resources Investigations Report 98-4063

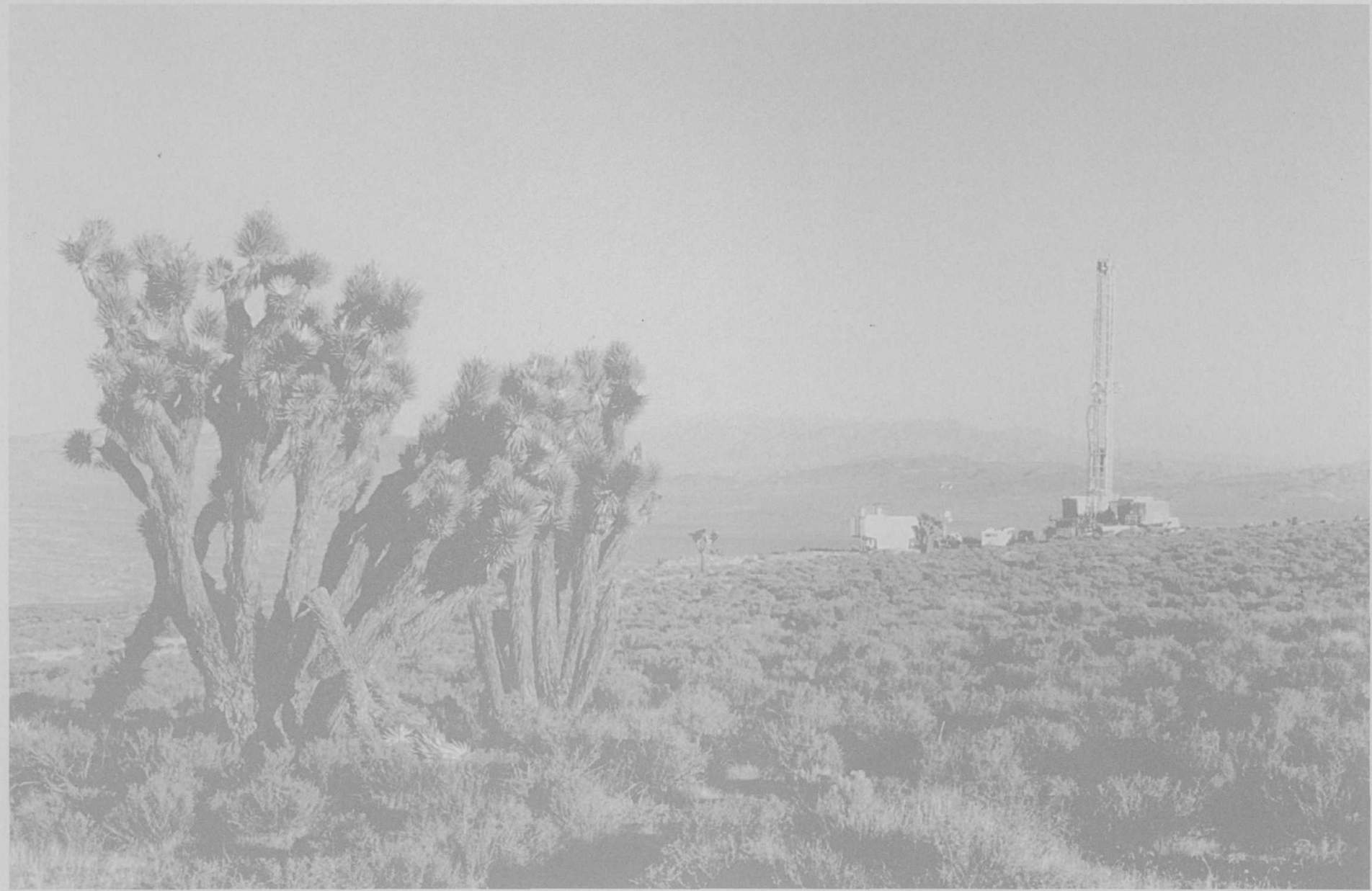

Prepared in cooperation with the

NEVADA OPERATIONS OFFICE,

U.S. DEPARTMENT OF ENERGY, under

Interagency Agreement DE-AI08-97NV12033 



\section{Analysis of Aquifer Tests Conducted in Borehole USW G-2, 1996, Yucca Mountain, Nevada}

by Grady M. O'Brien

U.S. GEOLOGICAL SURVEY

Water-Resources Investigations Report 98-4063

Prepared in cooperation with the NEVADA OPERATIONS OFFICE,

U.S. DEPARTMENT OF ENERGY, under

Interagency Agreement DE-Al08-97NV12033 


\section{U.S. DEPARTMENT OF THE INTERIOR BRUCE BABBITT, Secretary}

U.S. GEOLOGICAL SURVEY

Thomas J. Casadevall, Acting Director

The use of firm, trade, and brand names in this report is for identification purposes only and does not constitute endorsement by the U.S. Geological Survey.

For additional information write to:

Chief, Earth Science Investigations Program

Yucca Mountain Project Branch

U.S. Geological Survey

Box 25046, Mail Stop 421

Denver Federal Center

Denver, CO 80225-0046
Copies of this report can be purchased from:

U.S. Geological Survey

Information Services

Box 25286

Federal Center

Denver, CO 80225 


\section{CONTENTS}

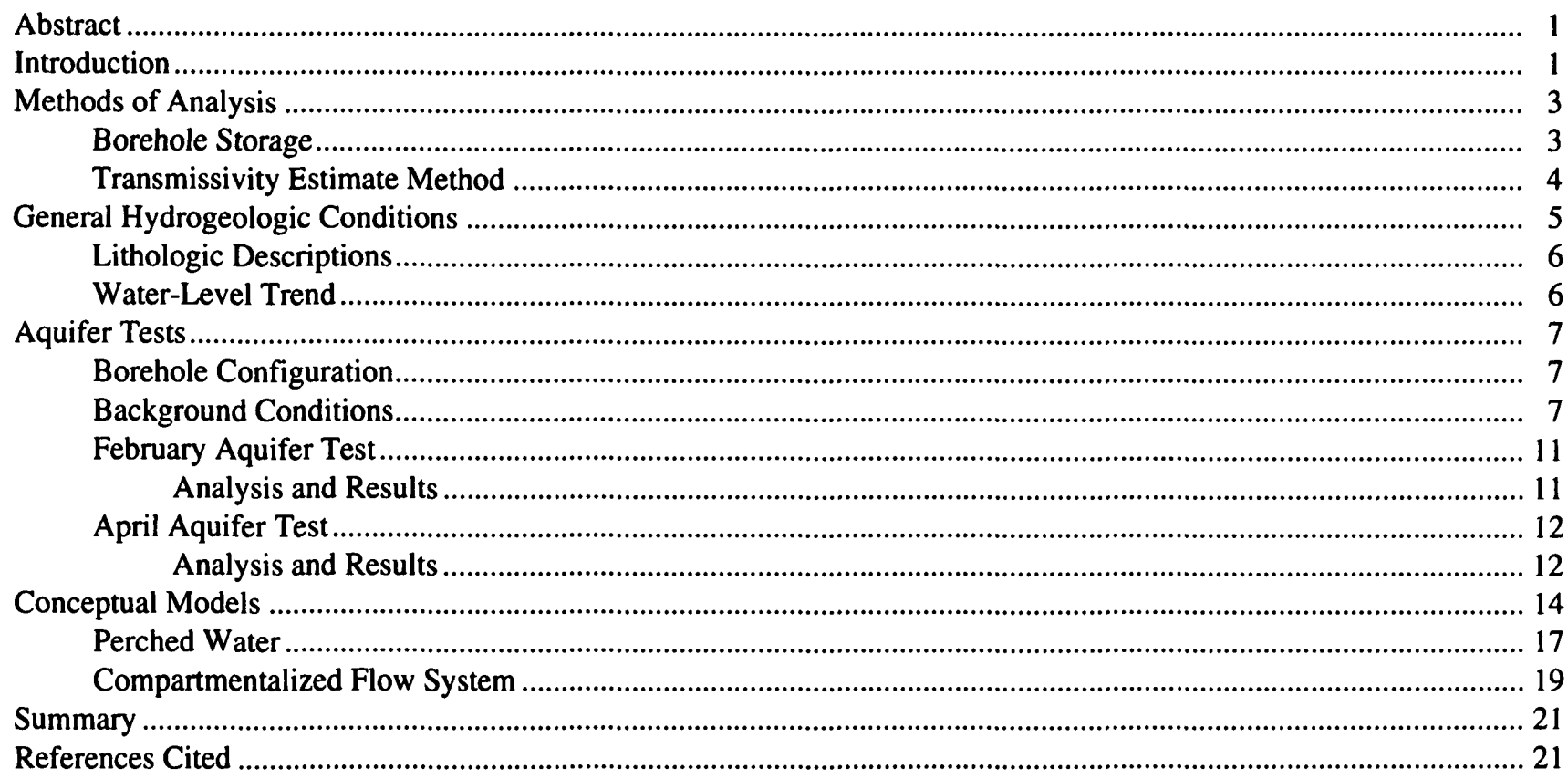

\section{FIGURES}

1. Map showing locations of selected deep boreholes near Yucca Mountain ....................................................... 2

2-3. Graphs showing:

2. Long-term water levels in borehole USW G-2, November 1981 to December 1996 .................................... 8

3. Water-level measurements and water-level trend, 1993-96, in borehole USW G-2 .................................... 9

4. Schematic diagram of borehole USW G-2 configuration during 1996 aquifer tests and geologic units

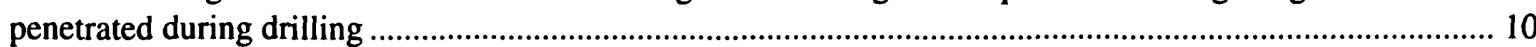

5-13. Graphs showing:

5. Flowmeter and manual discharge measurements as a function of time during February 1996 aquifer test in borehole USW G-2

6. Aquifer-test analysis by straight-line analytical solution for drawdown data during February 1996 test in borehole USW G-2

7. Aquifer-test analysis by straight-line analytical solution for recovery data from February 1996 test in borehole USW G-2.

8. Drawdown and recovery data from the February 1996 aquifer test in borehole USW G-2 2........................... 15

9. Flowmeter and manual discharge measurements as a function of time during the April 1996 aquifer test in borehole USW G-2

10. Drawdown data for the February and April 1996 aquifer tests in borehole USW G-2 ….............................. 17

11. Aquifer-test analysis by straight-line analytical solution for drawdown data during the April 1996 test in borehole USW G-2

12. Aquifer-test analysis by straight-line analytical method for recovery data from the April 1996 test in borehole USW G-2

13. April 1996 aquifer-test recovery data and water-level trend in borehole USW G-2

14. Schematic cross section of possible compartmentalized flow system intersected by borehole USW G-2 ..... 20 


\section{TABLES}

1. Water-level altitude in borehole USW G-2 measured manually between November 1981 and December 1993

2-4. Summary of:

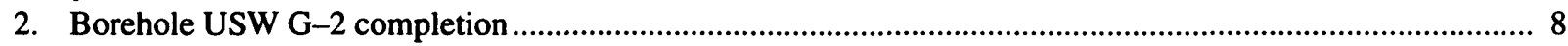

3. Pumping in borehole USW G-2 during aquifer testing, 1996..............................................................

4. Transmissivity estimates obtained from the February and April 1996 aquifer tests in borehole USW G-2

\section{CONVERSION FACTORS}

\begin{tabular}{rll}
\hline Multiply & By & To obtain \\
\hline millimeter $(\mathrm{mm})$ & 0.03937 & inch \\
meter $(\mathrm{m})$ & 3.281 & feet \\
kilometer $(\mathrm{km})$ & 0.6214 & mile \\
square kilometer $\left(\mathrm{km}^{2}\right)$ & 0.3861 & square mile \\
$\operatorname{liter}(\mathrm{L})$ & 0.2642 & gallon \\
liter per second $(\mathrm{L} / \mathrm{s})$ & 15.85 & gallons per minute \\
meter squared per day $\left(\mathrm{m}^{2} / \mathrm{day}\right)$ & 10.76 & foot squared per day \\
meter cubed per day per meter $\left(\mathrm{m}^{3} / \mathrm{day} / \mathrm{m}\right)$ & 10.76 & foot cubed per day per foot \\
\hline
\end{tabular}

Degree Celsius $\left({ }^{\circ} \mathrm{C}\right)$ may be converted to degree Fahrenheit $\left({ }^{\circ} \mathrm{F}\right)$ by using the following equation:

$$
{ }^{\circ} \mathrm{F}=\left(1.8 \times{ }^{\circ} \mathrm{C}\right)+32 .
$$

Sea level: In this report "sea level" refers to the National Geodetic Vertical Datum of 1929 (NGVD of 1929)_a geodetic datum derived from a general adjustment of the first-order level nets of both the United States and Canada, formerly called Sea Level Datum of 1929. 


\title{
Analysis of Aquifer Tests Conducted in Borehole USW G-2, 1996, Yucca Mountain, Nevada
}

\author{
By Grady M. O'Brien
}

\section{Abstract}

Borehole USW G-2 is located north of Yucca Mountain in a large-hydraulic-gradient area. Two single-borehole aquifer tests were conducted in the borehole during 1996. A 54.9-hour pumping period was conducted February 6-8, 1996, and a 408-hour pumping period was conducted April 8-25, 1996. The purpose of testing was to obtain estimates of the aquifer-system transmissivity and to determine if perched water was affecting the observed water level in borehole USW G-2. This report presents and analyzes data collected between February 6 and December 17, 1996.

Analysis of the aquifer-test data indicated that fracture flow, dual-porosity flow, and boundary-affected flow conditions were observed in the drawdown and recovery data. Transmissivity estimates ranged from 2.3 to 12 meters squared per day. The most representative transmissivity estimate for the interval tested is the early-time mean transmissivity of 9.4 meters squared per day. The Calico Hills Formation was the primary formation tested, but the top 3 meters of the nonpumping water column was within the overlying Topopah Spring Tuff.

Persistent residual drawdown following pumping more than 6 million liters of water during aquifer testing may indicate that the borehole intersected a perched water body. After 236 days of recovery, residual drawdown was 0.5 meter. The quantitative effect of the perched water on the observed water level in borehole USW G-2, however, cannot be determined with the available data.

\section{INTRODUCTION}

The U.S. Geological Survey is conducting hydrologic and geologic investigations of Yucca Mountain, Nevada, to determine its suitability to store high-level nuclear waste in an underground mined geologic repository. The site area, approximately 150 square kilometers $\left(\mathrm{km}^{2}\right)$, is about 150 kilometers $(\mathrm{km})$ northwest of Las Vegas in southern Nevada. In the Yucca Mountain area, the regional water table ranges from about 275 to 750 meters $(\mathrm{m})$ below the ground surface. The geologic units monitored in the saturated zone are ash-flow and air-fall tuffs of Tertiary age, which are underlain by carbonate rock of Paleozoic age.

Borehole USW G-2 is located north of Yucca Mountain (fig. 1). A large hydraulic gradient, defined by the water level in USW G-2 and two other boreholes, exists in the regional water table to the north of Yucca Mountain. In the large-hydraulic-gradient area, water-level altitudes range from 738 to $1,034 \mathrm{~m}$, and the hydraulic gradient is 0.11 (Tucci and Burkhardt, 1995). The water level in USW G-2 is about $290 \mathrm{~m}$ higher than the water level in boreholes to the south (Graves and others, 1996). Perched water may be contributing to the observed water levels and hydraulic gradient north of Yucca Mountain (Czarnecki and others, 1994). It is possible that the large hydraulic gradient is overestimated because of perched water that influences the observed water levels.

Borehole USW G-2 has been studied previously by several investigators. Geophysical logs have been completed in USW G-2 and are available in Nelson and Schimschal (1993) and Nelson and others (1991). Injection-type borehole flow surveys were completed in 1981 (Fenix and Scisson, Inc., written commun., 1981), and the results are briefly discussed in Luckey and others (1996). Heat-pulse flow surveys have also 


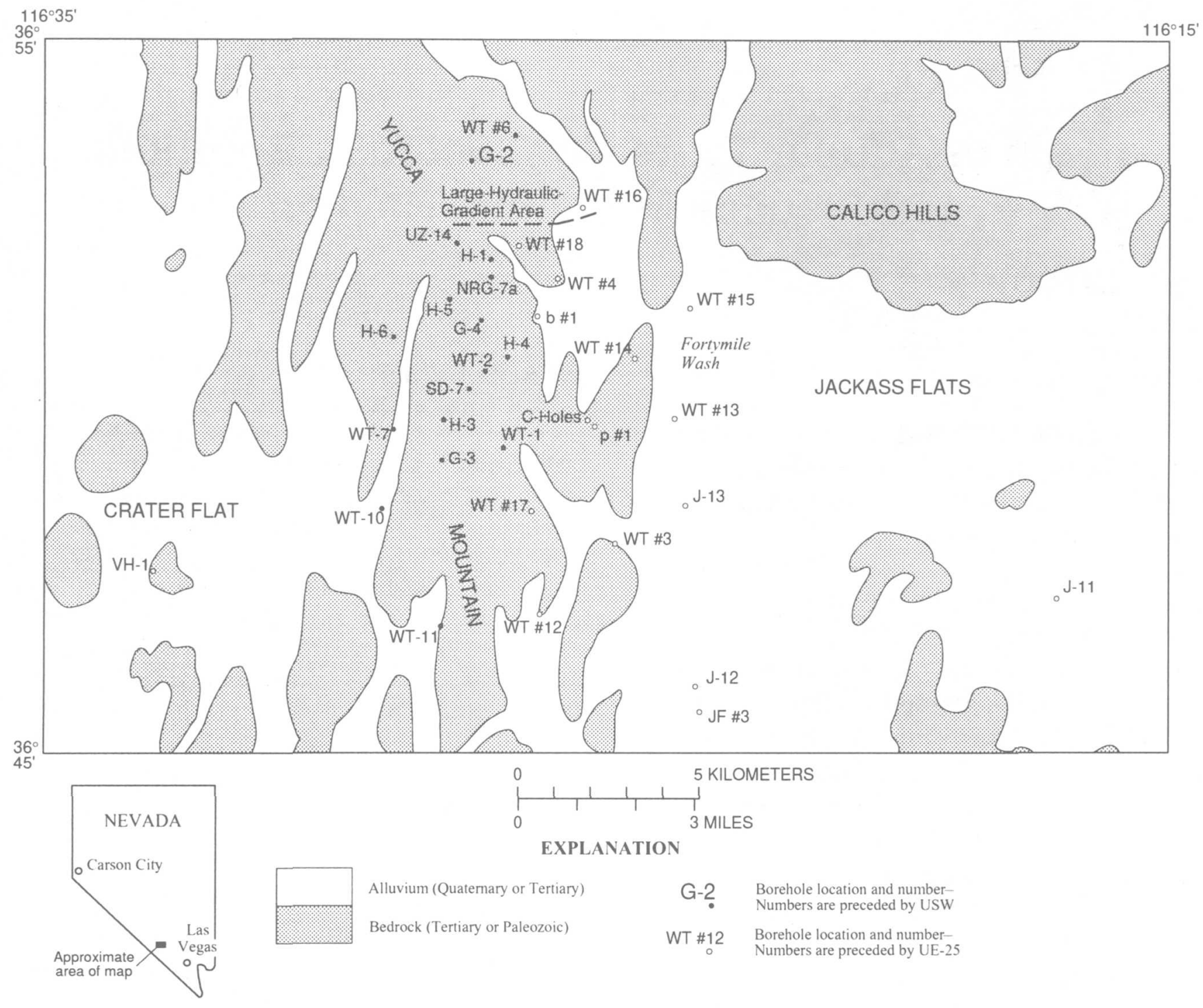

Figure 1. Locations of selected deep boreholes near Yucca Mountain.

been completed in borehole USW G-2 (F.L. Paillet, U.S. Geological Survey, written commun., 1994). The aquifer testing presented in this report is based on aquifer-test data that are available from boreholes in the large-hydraulic-gradient area.

Aquifer tests were conducted in 1996 in borehole USW G-2. During these aquifer tests water levels were monitored in the borehole with calibrated pressure transducers controlled by electronic data loggers. Prior to and after pumping, water levels were manually measured with calibrated steel tapes. The borehole was pumped with a submersible pump, and pump discharge was measured with a calibrated flowmeter and by manual volumetric measurements.

This investigation was conducted in cooperation with the U.S. Department of Energy under Interagency
Agreement DE-AI08-97NV12033 as part of the Yucca Mountain Site Characterization Project. Data used by the Yucca Mountain Project are classified as either qualified or unqualified. Qualified data are acquired or developed for the Yucca Mountain Project under a Nuclear Regulatory Commission accepted quality-assurance plan or qualified in accordance with appropriate Yucca Mountain Project procedures. Unqualified data were obtained prior to the implementation of the accepted Yucca Mountain Project qualityassurance program in 1989. All aquifer-test data analyzed in this report were collected as required by the U.S. Geological Survey, Yucca Mountain Project Branch quality-assurance program and are therefore considered qualified. All of the data used to determine water-level trends are considered unqualified because 
the reference point altitude for USW G-2 and information used to calculate the borehole deviation were obtained prior to the implementation of the qualityassurance program in 1989.

The purpose of this report is to estimate aquifersystem transmissivity and provide evidence of the effect of perched water on the observed water level in the borehole. Descriptions, analysis, and interpretations of the single-borehole aquifer tests conducted in borehole USW G-2 during 1996 are presented. Waterlevel and related data collected during aquifer testing in borehole USW G-2 between February 6 and December 17, 1996, and the subsequent analysis and interpretation of these data are included in this report.

\section{METHODS OF ANALYSIS}

The methods used to estimate the aquifersystem transmissivity in borehole USW G-2 were limited to solutions applicable to single-borehole aquifer tests. Transmissivity was estimated by analyzing the drawdown and recovery data using the Cooper and Jacob (1946) straight-line method. Timedistance methods could not be used because observation boreholes were not located within the area affected by pumping. The match of drawdown and recovery data to Theis type curves was poor and is not presented. Type-curve analysis is generally not appropriate in pumped wells because of water-level measurement errors that are introduced by variations in discharge and potential well losses.

Single-borehole tests generally cannot provide reliable estimates of aquifer storage. Solutions can be used to estimate specific yield in the pumped borehole if the radius of the borehole is known (Cooper and Jacob, 1946; Lohman, 1963; Lohman, 1979). These methods, however, should not be used when the radius of the borehole is uncertain (Ferris and others, 1962; Lohman, 1979). Caliper logs in USW G-2 (Nelson and others, 1991) indicate that the borehole wall is irregular and generally larger than the drill-bit diameter. The effective radius of the borehole cannot be accurately determined, so specific yield was not determined because the results would be unreliable. A reasonable specific yield for an unconfined, fracturedrock aquifer of 0.01 (Freeze and Cherry, 1979) was assumed when required.

\section{Borehole Storage}

Early time aquifer-test data can be affected by borehole storage and may not fit Jacob's modification of the nonequilibrium theory (Schafer, 1978). Analysis of the early-time drawdown data that are affected by borehole storage could result in erroneous transmissivity estimates. When pumping is started, the water in the borehole is removed first. As the water level in the borehole drops, water begins to enter the borehole from the surrounding aquifer system. As pumping continues, a greater percentage of the borehole yield comes from the aquifer (Driscoll, 1986, p. 232). Two methods for determining when borehole storage is negligible have been developed by Schafer (1978) and Weeks (1978) and are used in this report.

Advantages of the method suggested by Schafer are that well efficiency and transmissivity do not need to be known. The time at which borehole storage is negligible is given by (Schafer, 1978):

$$
t_{c}=\frac{0.017\left(d_{w}{ }^{2}-d_{p}{ }^{2}\right)}{Q / s}
$$

where $t_{c}=$ time when borehole storage effect becomes negligible, in minutes;

$d_{w}=$ diameter of the borehole, in millimeters (mm);

$d_{p}=$ outside diameter of the pump column pipe, in $\mathrm{mm}$; and

$Q / s=$ specific capacity of the borehole at time $t_{c}$, in cubic meters per day per meter $\left(\mathrm{m}^{3} / \mathrm{day} / \mathrm{m}\right)$.

Weeks (1978) modified the Papadopulos and Cooper (1967) method to determine the minimum pumping time required for an aquifer test. The radius of the borehole and aquifer transmissivity are required to obtain the estimated time of borehole storage in equation 2 (Weeks, 1978).

$$
t>25 r_{c}^{2} / T
$$

where $t=$ time when borehole storage effect becomes negligible, $(\mathrm{t})$;

$r_{c}=$ radius of the borehole, $(\mathrm{L})$;

$T=$ transmissivity, $\left(\mathrm{L}^{2} / \mathrm{t}\right)$.

( $\mathrm{L}=$ consistent unit of length;

$\mathrm{t}=$ consistent $\mathrm{unit}$ of time) 
The Schafer and Weeks methods require that the borehole diameter be known. Borehole USW G-2 is an open hole below the water table, and the hole diameter is variable throughout the saturated section. The drilled borehole diameter in the interval tested is $222 \mathrm{~mm}$, and caliper logs indicate a maximum borehole diameter of about $250 \mathrm{~mm}$.

The period of borehole-storage effects for the February and April aquifer tests was calculated by using equations 1 and 2 . Borehole-storage effects last for about the first 20 minutes of pumping when 250-mm hole diameter, $95-\mathrm{mm}$ pump diameter, and $47.8 \mathrm{~m}^{3} / \mathrm{day} / \mathrm{m}$ specific capacity (3.6 liters per second [L/s] pump discharge and $6.5 \mathrm{~m}$ of drawdown) are used in equation 1. Borehole-storage effects are predicted to dominate the drawdown response for about the first 47 minutes of pumping when equation 2 is used with a transmissivity of 12 meters squared per day $\left(\mathrm{m}^{2} /\right.$ day) and a hole radius of $125 \mathrm{~mm}$. A unit slope on a log-log plot of drawdown as a function of time is often used to identify borehole-storage effects (Earlougher, 1977, p. 11). Aquifer testing in borehole USW G-2, however, resulted in less than 5 minutes of unit slope on a log-log drawdown plot. Weeks' method provides a conservative estimate of boreholestorage effects, and drawdown data collected during the first 47 minutes of pumping were not analyzed.

\section{Transmissivity Estimate Method}

Cooper and Jacob (1946) developed a straightline graphical method to estimate the transmissivity (eq. 3) from drawdown data in a pumped borehole. This method does not require type-curve matching or observation wells. Theis (1935) initially derived the nonequilibrium formula, and Cooper and Jacob (1946) realized that the formula could be simplified when $u$ (eq. 4) becomes sufficiently small. The simplified equation is referred to as the modified nonequilibrium formula. For convenience, the modified nonequilibrium formula is solved by using the change in drawdown over one logarithmic cycle of time. The analysis method requires that drawdown, $s$, be plotted on the arithmetic scale and time, $t$, be plotted on the logarithmic scale. The graphical, semilogarithmic formula simplifies to the following form when used with the specified units:

$$
T=\frac{15.8 Q}{\Delta s}
$$

where $T=$ transmissivity, in $\mathrm{m}^{2} /$ day;

$Q=$ discharge, in $\mathrm{L} / \mathrm{s}$; and

$\Delta s=$ change in drawdown over one log cycle of time, in meters.

Use of the straight-line method is only applicable at times when $u$, as defined by equation 4 , is less than or equal to about 0.01 (Cooper and Jacob, 1946; Lohman, 1979, p. 22). Consistent units must be used when solving equation 4 to estimate $u$.

$$
u=\frac{r^{2} S_{y}}{4 T t}
$$

where $r=$ distance from discharging well to point of observation of drawdown (L);

$S_{y}=$ specific yield, (dimensionless);

$T=$ transmissivity, $\left(\mathrm{L}^{2} / \mathrm{t}\right)$; and

$t=$ time since pumping began, $(\mathrm{t})$.

$(\mathrm{L}=$ consistent unit of length;

$\mathrm{t}=$ consistent unit of time)

The pumping time in an unconfined aquifer must be long enough to allow reasonably complete drainage of material within the part of the cone of depression being observed (Lohman, 1979). Data points will fall on a straight line only after the time, $t$, is sufficiently long to satisfy the criteria of $u<0.01$. Unconfined aquifers require longer pumping time to reduce the value of $u$ because specific yield is generally several orders of magnitude larger than the storage coefficient in confined aquifers (Lohman, 1979). Borehole USW G-2 is completed in fractured rock, which typically has lower specific yield than unconsolidated materials under water-table conditions. By using a conservative specific-yield estimate of 0.01 , transmissivity of $12 \mathrm{~m}^{2} / \mathrm{day}$, and a $0.125-\mathrm{m}$ borehole radius in equation 4 , the value of $u$ is equal to 0.01 after less than 1 minute of pumping. Drawdown data do not form a straight line until $u$ is much less than 0.01 , if there is matrix drainage.

The nonequilibrium formula, and formulas subsequently derived from it, are based on the following assumptions: (a) the aquifer is homogeneous and isotropic; (b) the aquifer has infinite areal extent; (c) the borehole penetrates and receives water 
from the entire thickness of the aquifer; (d) transmissivity is constant at all times and at all places; (e) the well has a reasonably small diameter; and (f) water removed from storage is discharged instantaneously with decline in head. It is doubtful that all of these assumptions were strictly met during aquifer testing in borehole USW G-2. Transmissivity estimates could be in error if the assumptions are violated, but the estimates are the best possible with the available methods and data.

Analysis of recovery data is generally preferable over drawdown data in single-borehole aquifer tests because errors introduced during pumping are not present. Recovery data can be used to validate the drawdown data that may be affected by well losses (Driscoll, 1986, p. 554). Water-level recovery data were analyzed with the Theis recovery formula (Theis, 1935), which is a corollary to the nonequilibrium formula and is applied in a similar manner as the modified nonequilibrium formula. The Theis recovery formula has the same form as equation 3 and is most conveniently solved with a semilogarithmic plot of residual drawdown, $s^{\prime}$, on the arithmetic scale, and dimensionless time, $t / t^{\prime}$, on the logarithmic scale. Dimensionless time is defined as the time since pumping started $(t)$ divided by the time since pumping ended $\left(t^{\prime}\right)$. After the value of $t^{\prime}$ becomes sufficiently large, the observed data should form a straight line (Ferris and others, 1962). Transmissivity is calculated by using equation 3 and by determining the change in residual drawdown over one logarithmic cycle of $t / t^{\prime}$. If a geologic boundary has been intersected by the cone of depression during pumping, it may be reflected in the rate of recovery in the pumped borehole, and the value of transmissivity determined by using the Theis recovery formula could be in error (Ferris and others, 1962). Early-time recovery data were analyzed by using the straight-line Theis recovery formula, but transmissivity is not reported for later time data because of boundary-induced errors.

\section{GENERAL HYDROGEOLOGIC CONDITIONS}

The interval tested in USW G-2 consists of the bottom $3 \mathrm{~m}$ of the Topopah Spring Tuff and the upper $256 \mathrm{~m}$ of the Calico Hills Formation. The Calico Hills Formation is most often considered an aquitard or confining unit in the Yucca Mountain area because of its low transmissivity (Winograd and Thordarson,
1975; Luckey and others, 1996). In this report the Calico Hills Formation is considered part of the aquifer system because it is the primary waterproducing unit tested.

The ash-flow and air-fall tuffs that are penetrated by USW G-2 vary in the degree of welding. The intensity of fracturing is highest in the densely welded zones (Maldonado and Koether, 1983). The Calico Hills Formation in the USW G-2 borehole is a fractured, primarily nonwelded tuff with thinly bedded tuff present. Maldonado and Koether (1983) identified 285 fractures within the $288.7 \mathrm{~m}$ thickness of the Calico Hills Formation in USW G-2. Two zones of drilling-induced fractures, in depth ranges from 541 to $570 \mathrm{~m}$ and from 648 to $678 \mathrm{~m}$, in the Calico Hills Formation were identified by Stock and others (1984). Most of these drilling-induced fractures probably do not transmit substantial volumes of water, and lithostatic pressure probably closes them at depth. Most of the flow, however, probably occurs through a few natural fractures, but the rock matrix may also contribute flow in a dual-porosity flow system. Flow through fractures and rock matrix is often referred to as dual-porosity flow and has been observed in other Yucca Mountain boreholes (Craig and Reed, 1991; Craig and Robison, 1984; Moench, 1984; Rush and others, 1984). Dual-porosity flow results in a decrease in the drawdown curve slope because water that drains from the rock matrix is contributing flow to the borehole.

There have been several attempts to identify and quantify transmissive intervals of borehole USW G-2, but the results were often ambiguous and difficult to interpret. A heat-pulse flow survey and geophysical logs obtained in November 1994 suggested that flow is controlled by a system of vertical fractures (F.L. Paillet, U.S. Geological Survey, written commun., 1994). A vertical fracture was identified that follows the borehole for most of the logged interval, which was to a depth of about $800 \mathrm{~m}$. Weak downward flow was indicated within the Calico Hills Formation between depths of 580 to $700 \mathrm{~m}$ (F.L. Paillet, U.S. Geological Survey, written commun., 1994). The Calico Hills Formation accepted all of the water injected during a tracer ejector borehole-flow survey in USW G-2 (Luckey and others, 1996, p. 37). Waterproducing intervals under pumping conditions, however, could be different than those identified under static and injection conditions. 


\section{Lithologic Descriptions}

Lithologic descriptions of the tested formations have been completed by Maldonado and Koether (1983) and Lipman and others (1966). The Topopah Spring Tuff and Calico Hills Formation within the tested interval are briefly described.

The Topopah Spring Tuff is a multiple ash-flow compound cooling unit (compositionally zoned). The compositional zonation grades from crystal-poor rhyolite at the base to crystal-rich quartz latite toward the top; petrographically the unit contains sanidine, plagioclase, biotite, and clinopyroxene phenocrysts (Lipman and others, 1966).

The Calico Hills Formation is composed essentially of nonwelded ash-flow tuff with 15 thin tuffaceous sedimentary beds that contain minor ashfall tuffs. The rocks are typically zeolitized and characterized by a decrease in quartz and sanidine and an increase in plagioclase and biotite phenocrysts with depth. An increase in phenocrysts and overall increase in lithic fragments was also observed with depth. The Calico Hills Formation at USW G-2 can be divided into three (upper, middle, and lower) subunits on the basis of mineral content (Maldonado and Koether, 1983, p. 21).

The upper subunit is $158.9 \mathrm{~m}$ thick and occurs in the depth interval 535.5 to $694.4 \mathrm{~m}$. The subunit is characterized by a relatively higher quartz-sanidine phenocryst content and lower biotite-plagioclase content than the underlying subunits. The subunit is pervasively zeolitized and ranges from 50 to 70 percent in zeolites (clinoptilolite and mordenite) as indicated by X-ray analysis. Seven tuffaceous sedimentary beds with minor ash-fall tuffs occur throughout the subunit (Maldonado and Koether, 1983, p. 21).

The middle subunit is $32.6 \mathrm{~m}$ thick and occurs in the depth interval 694.4 to $727.0 \mathrm{~m}$. This subunit could possibly represent the mineralogic transition in phenocryst content from a high quartz-sanidine to a low quartz-sanidine. The interval is also characterized by alternating thin ash-flow tuffs with thin tuffaceous sediments with some ash-fall tuffs (Maldonado and Koether, 1983, p. 21).

The lower subunit is $97.2 \mathrm{~m}$ thick, occurs in the depth interval 727.0 to $824.0 \mathrm{~m}$, and contains a relatively higher plagioclase-biotite phenocryst and lower quartz-sanidine phenocryst content than overlying subunits. Quartz phenocrysts are slightly resorbed. The zeolite (mordenite and clinoptilolite) content is estimated to range from 30 to 50 percent, a decrease from the overlying subunits (Maldonado and Koether, 1983, p. 21).

\section{Water-Level Trend}

Water-level trends in USW G-2 are evaluated because of the possibility of perched water affecting the observed level. It is necessary to account for natural water-level trends that may affect the calculation of residual drawdown. Declining water levels may also indicate draining of a perched water body. Historic depth-to-water (DTW) measurements indicate that a long-term declining water-level trend exists in borehole USW G-2. Water levels have been measured periodically during two periods: from November 1981 to September 1982 and from February 1993 to December 1996 (table 1 and fig. 2). Water-level measurements after October 10,1995, were affected by pumping and do not represent the static level. Monitoring was discontinued between September 1982 and February 1993 because other studies were using the borehole. During the early 1980's the rate of water-level decline was $3.5 \mathrm{~m} /$ year. Measurements since 1993 indicate that the rate of water-level decline has slowed considerably since the early 1980's (table 1 and fig. 2). Based on a linear regression of the 13 measurements between February 3, 1993, and October 10, 1995, the rate of water-level decline was $0.190 \mathrm{~m} /$ year (fig. 3).

The water-level measurement on October 10, 1995, was made before any water was removed from the borehole and is the undisturbed baseline level for all testing. Water levels were affected for extended periods of time owing to pumping in the borehole after October 10, 1995. The February and April 1996 aquifer tests were initiated while the borehole was recovering from previous pumping, and the undisturbed water level could not be directly measured. The undisturbed water level and residual drawdown are based on the DTW measured on October 10, 1995, and the linear water-level trend of $-0.190 \mathrm{~m} /$ year. The estimated water level can be calculated by using equation 5 . 
$1,019.91 \mathrm{~m}-(\mathrm{X} \times(1$ year/365.25 day $) \times$

$0.190 \mathrm{~m} /$ year $)=$ estimated undisturbed

water level $\times$ days after October 10, 1995,

where $1,019.91 \mathrm{~m}=$ water-level altitude measured on October 10, 1995;

$\mathrm{X}=$ number of days since October 10, 1995;

$0.190 \mathrm{~m} /$ year $=$ estimated rate of water-level decline.

Table 1. Water-level altitude in borehole USW G-2 measured manually between November 1981 and December 1996 (Graves and others, 1996; Tucci and others, 1996; Robison and others, 1988)

\begin{tabular}{cc}
\hline $\begin{array}{c}\text { Date of } \\
\text { measurement }\end{array}$ & $\begin{array}{c}\text { Water-level altitude above } \\
\text { sea level (meters) }\end{array}$ \\
\hline $11 / 10 / 81$ & $1,031.82$ \\
$11 / 30 / 81$ & $1,031.16$ \\
$12 / 9 / 81$ & $1,030.98$ \\
$9 / 17 / 82$ & $1,028.84$ \\
$2 / 3 / 93$ & $1,020.38$ \\
$3 / 10 / 93$ & $1,020.36$ \\
$4 / 19 / 93$ & $1,020.34$ \\
$5 / 7 / 93$ & $1,020.37$ \\
$6 / 28 / 93$ & $1,020.37$ \\
$10 / 20 / 93$ & $1,020.17$ \\
$11 / 24 / 93$ & $1,020.18$ \\
$12 / 29 / 93$ & $1,020.11$ \\
$2 / 3 / 94$ & $1,020.18$ \\
$2 / 18 / 94$ & $1,020.30$ \\
$11 / 14 / 94$ & $1,019.98$ \\
$12 / 14 / 94$ & $1,020.04$ \\
$10 / 10 / 95$ & $1,019.91$ \\
$11 / 2 / 95$ & $1,019.58$ \\
$12 / 5 / 95$ & $1,019.74$ \\
$12 / 11 / 95$ & $1,019.75$ \\
$1 / 17 / 96$ & $1,019.81$ \\
$6 / 3 / 96$ & $1,015.61$ \\
$8 / 26 / 96$ & $1,019.05$ \\
$12 / 17 / 96$ & $1,019.21$ \\
\hline &
\end{tabular}

\section{AQUIFER TESTS}

\section{Borehole Configuration}

The borehole configuration during aquifer testing and geologic units penetrated during drilling are schematically illustrated in figure 4 and summarized in table 2. A bridge plug, used for a previous study, was located at a depth of $808 \mathrm{~m}$ on December 4, 1990. Fill on top of the bridge plug was located at a depth of $804 \mathrm{~m}$ on September 21, 1995. The physical condition of the plug and the degree that it is restricting flow in the borehole is unknown. An inflatable packer was set at a depth of $792 \mathrm{~m}$ on September 28, 1995, to isolate the borehole above the bridge plug. Hydrofracture stress measurements during previous studies, however, probably failed because of fractures hydraulically connecting packedoff intervals between depths of 581 and $810 \mathrm{~m}$ (Stock and others, 1984). It is unknown if the lower portion of the borehole was effectively isolated by the packer during the aquifer tests. Transmissivity estimates are assumed to be valid for the portion of the borehole above the packer.

\section{Background Conditions}

No natural weather systems or human-induced interference are believed to have affected the aquifer tests. The Yucca Mountain area is arid and no significant precipitation occurred during any of the testing periods. Depth to water at the borehole was about $533 \mathrm{~m}$ and the time for infiltration of any surface precipitation to reach the water-bearing zones is considered too long to impact water levels during aquifer testing. Discharged water was piped approximately $450 \mathrm{~m}$ away from the borehole and dispersed with a sprinkler system. No discharging wells or perennial surface-water features were located within several kilometers of USW G-2. Due to these conditions, no significant human-induced or precipitationinduced influences on the water levels occurred during aquifer testing. Passing weather fronts commonly produce barometric-pressure changes that can have minor effects (generally less than $0.10 \mathrm{~m}$ ) on water levels in Yucca Mountain boreholes. Water-level fluctuations due to barometric pressure are accounted for by assuming that the borehole has a barometric efficiency of 100 percent. This assumption is reasonable 


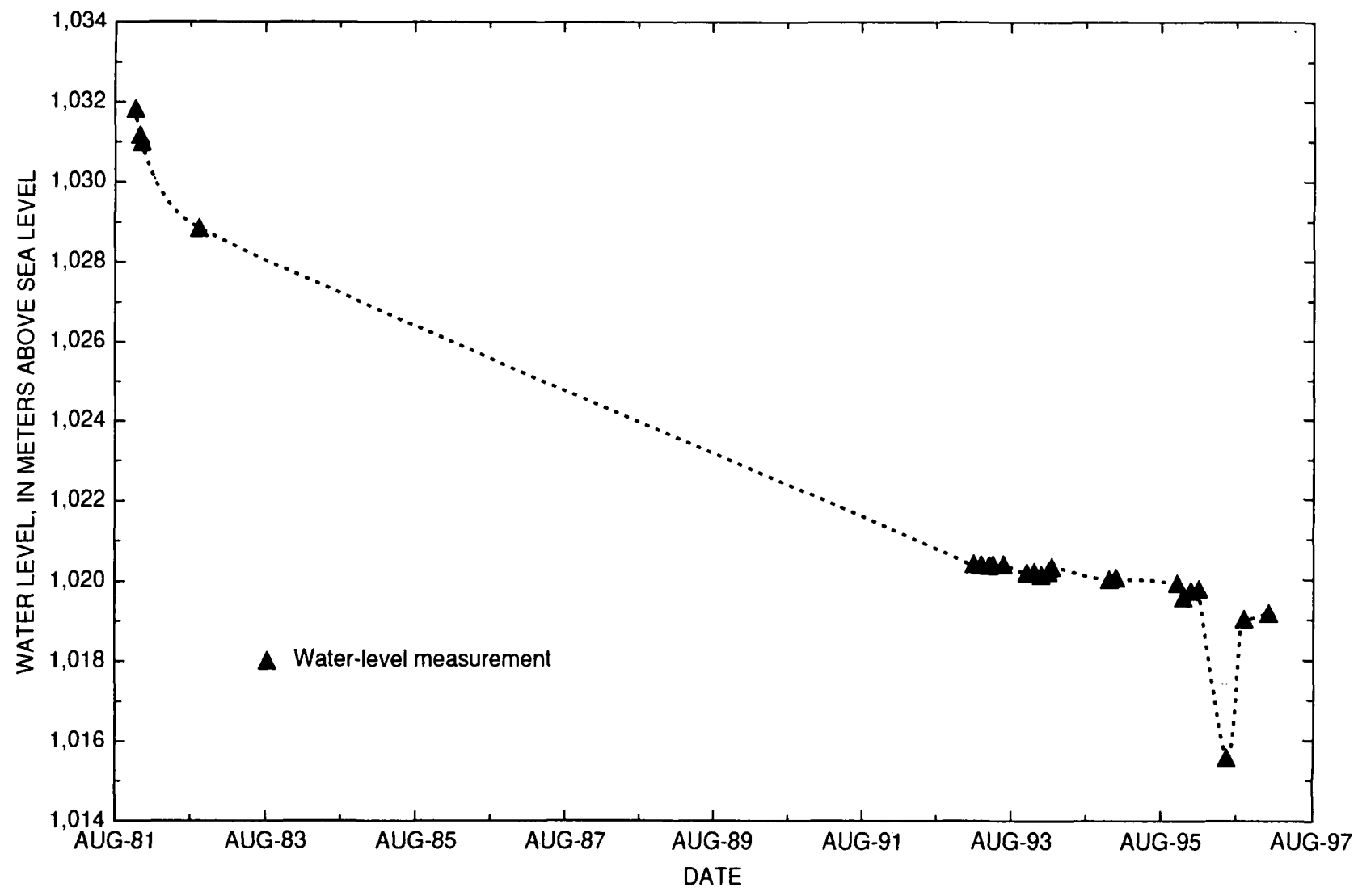

Figure 2. Long-term water levels in borehole USW G-2, November 1981 to December 1996.

Table 2. Summary of borehole USW G-2 completion

\begin{tabular}{ccccccc}
\hline $\begin{array}{c}\text { Borehole location } \\
\text { (latitude, longitude) }\end{array}$ & $\begin{array}{c}\text { Total drilled } \\
\text { depth } \\
\text { (meters) }\end{array}$ & $\begin{array}{c}\text { Depth of } \\
\text { casing } \\
\text { (meters) }\end{array}$ & $\begin{array}{c}\text { Drilled hole } \\
\text { diameter } \\
\text { in interval } \\
\text { tested } \\
\text { (meters) }\end{array}$ & $\begin{array}{c}\text { Interval } \\
\text { tested } \\
\text { (meters) }\end{array}$ & $\begin{array}{c}\text { Interval } \\
\text { thickness } \\
\text { (meters) }\end{array}$ & $\begin{array}{c}\text { Geologic units } \\
\text { in tested } \\
\text { interval }\end{array}$ \\
\hline $\begin{array}{c}36^{\circ} 53^{\prime} 22^{\prime \prime} \mathrm{N} \\
116^{\circ} 27^{\prime} 35^{\prime \prime} \mathrm{W}\end{array}$ & 1,831 & 242 & 0.222 & $533-792$ & 259 & $\begin{array}{c}\text { Topopah Spring Tuff } \\
\text { (3 meters) and Calico Hills } \\
\text { Formation (256 meters) }\end{array}$ \\
\hline
\end{tabular}

'Top of interval is the water table, bottom of interval is top of inflatable packer. 


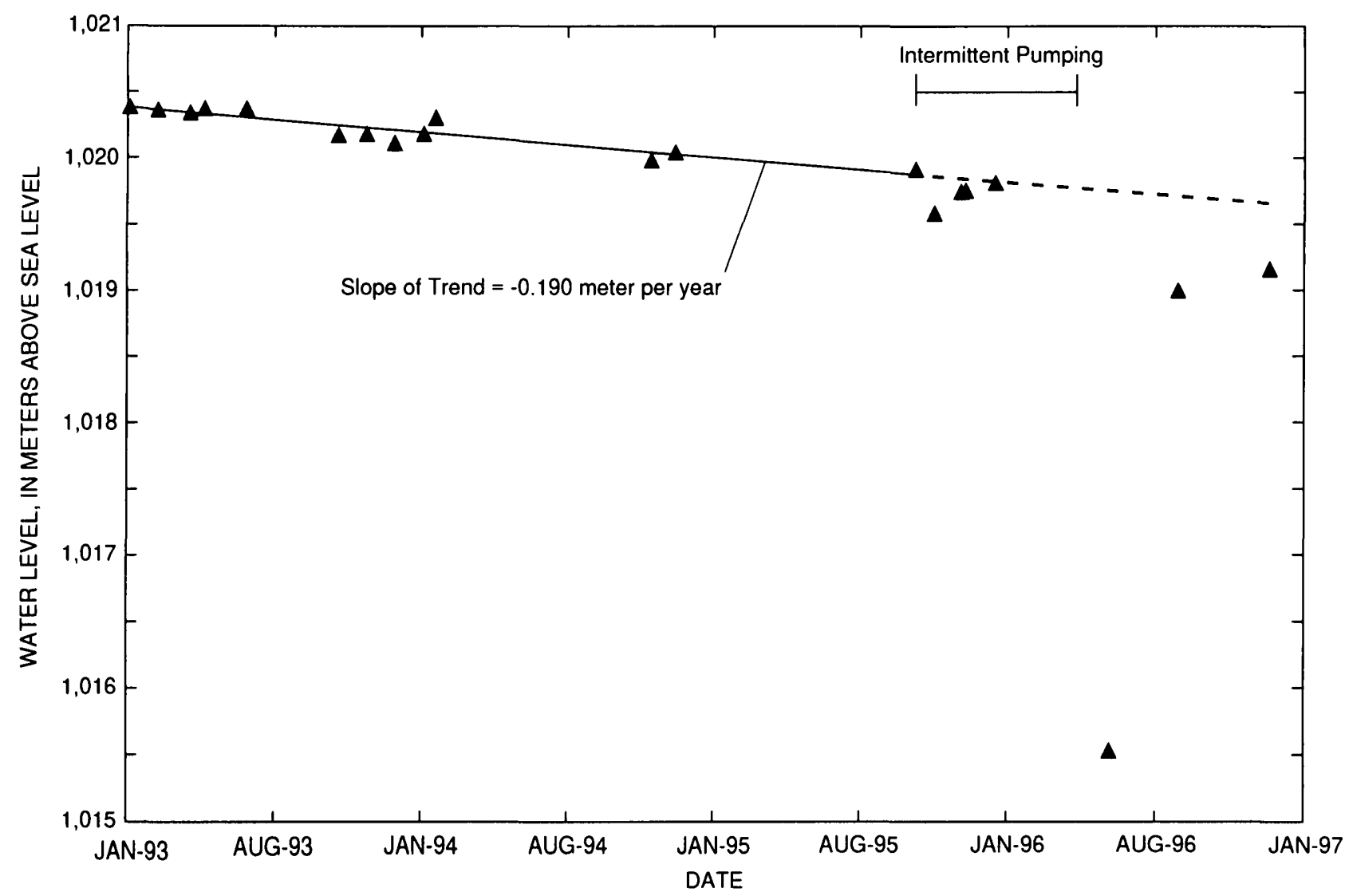

Figure 3. Water-level measurements and water-level trend, 1993-96, in borehole USW G-2.

given observations of the static and pumping waterlevel fluctuations due to barometric-pressure fluctuations. Barometric efficiency near 100 percent has also been estimated in other Yucca Mountain boreholes (A.L. Geldon, U.S. Geological Survey, written commun., 1996).

Hydraulic-conductivity estimates were not calculated because of the ambiguity in determining what portions of the borehole were producing water during pumping. Flow does not appear to be equally distributed throughout the saturated portion of the borehole, and hydraulic-conductivity estimates derived from transmissivity and the saturated thickness would most likely be misleading.

Water levels in borehole USW G-2 were affected by several pumping periods between October 1995 and April 1996. Equipment tests required several pumping cycles between October and early February 1996. Although these pumping cycles were generally only a few hours, water levels did not fully recover for several days. The borehole was pumped for 54.9 hours between February 6 and February 8, 1996, and the water levels did not return to their undisturbed level after 60 days of recovery. The longest pumping period in USW G-2 was 408 hours between April 8 and April 25, 1996. After 236 days of recovery, the water level had not recovered to its undisturbed level. A summary of pumping for the February and April, 1996, aquifer tests conducted in borehole USW G-2 is presented in table 3.

Water levels were measured by a submersible pressure transducer on at least an hourly interval. At the start of pumping and after pumping was stopped, water levels were measured as frequently as every minute.

Pump discharge was measured manually and by an electronic flowmeter throughout the pumping phases of the aquifer tests. The manual volumetric method of measuring discharge was used to verify the output of the electronic clamp-on flowmeter. Manual volumetric-discharge measurements were obtained by measuring the time for pumped water to fill a container of known volume. 


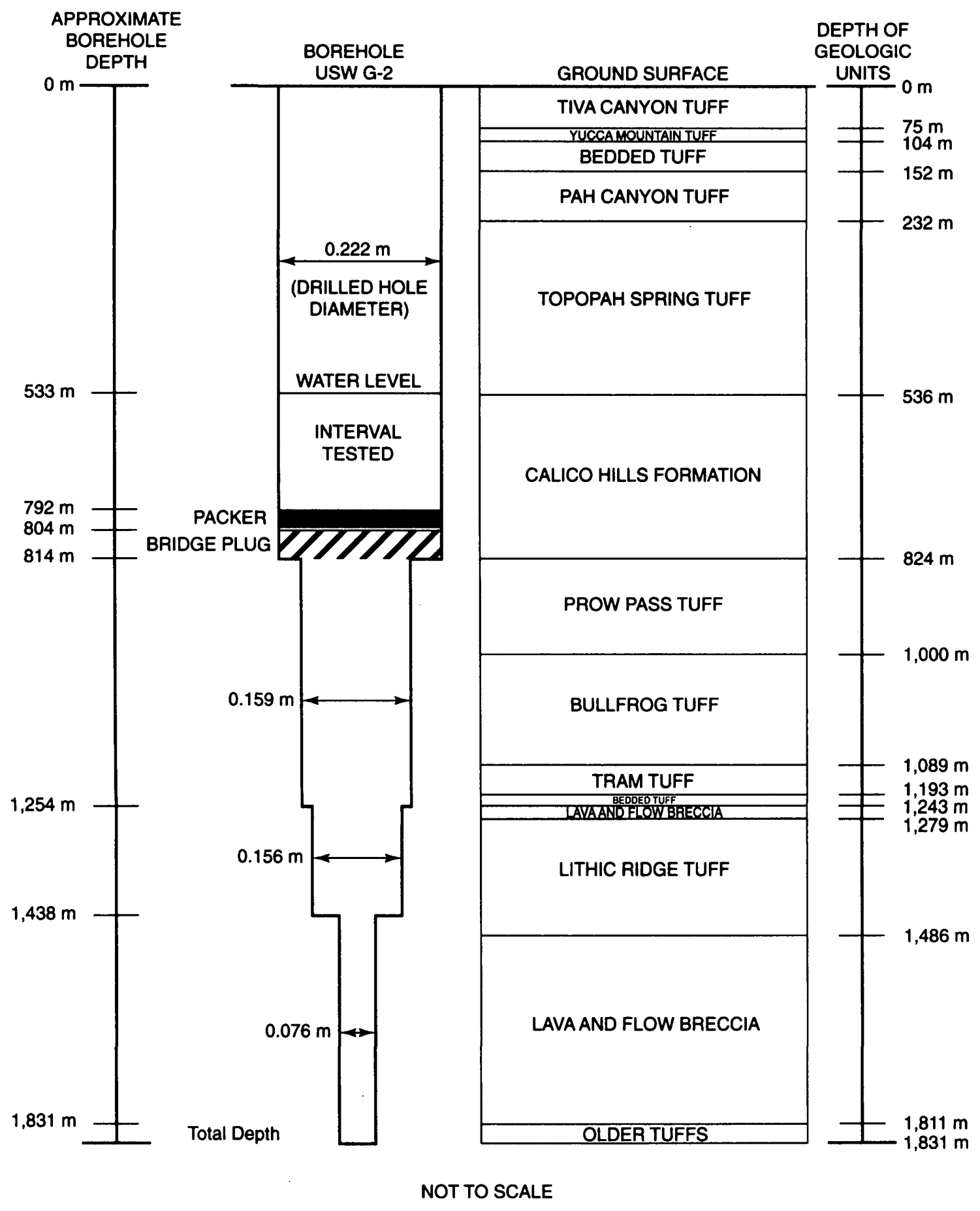

Figure 4. Schematic diagram of borehole USW G-2 configuration during 1996 aquifer tests and geologic units penetrated during drilling. (Stratigraphy from Maldonado and Koether, 1983.) 
Table 3. Summary of pumping in borehole USW G-2 during aquifer testing, 1996

\begin{tabular}{|c|c|c|c|c|}
\hline Test period & $\begin{array}{l}\text { Date and time } \\
\text { pump on or off }\end{array}$ & $\begin{array}{l}\text { Duration } \\
\text { of pumping } \\
\text { (hours) }\end{array}$ & $\begin{array}{l}\text { Mean discharge } \\
\text { (liters/second) }\end{array}$ & $\begin{array}{c}\text { Total } \\
\text { discharge } \\
\text { (liters) }\end{array}$ \\
\hline February & $\begin{array}{ll}\text { On: } 02 / 06 / 96 & 09: 15 \\
\text { Off: } 02 / 08 / 96 & 16: 06\end{array}$ & 54.9 & 3.66 & 720,000 \\
\hline April & $\begin{array}{ll}\text { On: } 04 / 08 / 96 & 09: 00 \\
\text { Off: } 04 / 25 / 96 & 09: 00\end{array}$ & 408 & 3.60 & $5,300,000$ \\
\hline
\end{tabular}

\section{February Aquifer Test}

A 72-hour aquifer test was planned and started on February 6, 1996. Generator failure on February 8 prematurely terminated pumping after 54.9 hours. Flowmeter and manual discharge measurements during the February test are presented in figure 5. There was close agreement between the flowmeter and manual discharge measurements although the flowmeter data appear more erratic owing to the high measurement frequency. Mean discharge was $3.66 \mathrm{~L} / \mathrm{s}$ and total discharge was estimated as $720,000 \mathrm{~L}$. The slow water-level recovery in USW G-2 following equipment testing resulted in $2.0 \mathrm{~m}$ of residual drawdown at the start of the February test. Water-level recovery was monitored for 60 days after pumping ended.

\section{Analysis and Results}

Aquifer-test data were analyzed with the straight-line method to estimate transmissivity. Three straight-line segments, representing different flow conditions during pumping, are present in the drawdown data. The first segment, represented by line 1 on figure 6 , is interpreted to represent predominantly fracture flow conditions and results in a transmissivity estimate of $8.8 \mathrm{~m}^{2} /$ day.

A decrease in the drawdown curve slope, represented by line 2 on figure 6 , is interpreted to represent dual-porosity flow conditions and results in a transmissivity estimate of $12 \mathrm{~m}^{2} /$ day. An approximate doubling of the drawdown curve slope occurs after about 1,700 minutes. The drawdown curve slope can double as a result of the cone of depression intersecting an aquifer boundary (Bruin and Hudson, 1955, p. 25). Late time drawdown data that are possibly affected by an aquifer boundary are represented by line 3 on figure 6 and result in a transmissivity of $6.2 \mathrm{~m}^{2} /$ day. Transmissivity determined from drawdown data that are influenced by dual porosity and aquifer boundaries is not representative of the entire aquifer and is generally not useful under non-pumping conditions.

Recovery data were analyzed by using the straight-line method by plotting drawdown on the linear $y$-axis and the ratio $t / t^{\prime}$ on the logarithmic $x$-axis (fig. 7). Increasing recovery time is from right to left in figure 7. Residual drawdown is the difference between the water level immediately prior to the start of pumping and the water level at a given time after pumping stopped. The long-term water-level trend is not accounted for in the residual drawdown analyzed because it results in a minor adjustment. Adjusting the data for residual drawdown at the start of pumping would shift the data, but would not change the slope of the data, so no adjustment was made.

Three straight-line segments were identified in the recovery data illustrated in figure 7. Early-time data, line 1 in figure 7, are interpreted to represent the recovery of water into fractures, and transmissivity is estimated as $9.6 \mathrm{~m}^{2} /$ day. The straight-line portions of drawdown data indicated by lines 2 and 3 in figure 7 are affected by the aquifer boundary, so transmissivity estimates are not reported for those data.

The recovery data should match the drawdown curve if the assumptions of the nonequilibrium equation were satisfied, the pumping rate was constant throughout the hydraulic test, and the aquifer was in hydraulic equilibrium before pumping began (Bruin and Hudson, 1955). Recovery data, however, were not a mirror image of the drawdown data (fig. 8), indicating that the system was not responding as predicted by porous-media flow theory. Drawdown and recovery data deviate substantially after about 200 minutes, which is the time that dual-porosity flow is interpreted to occur. Boundary effects may be contributing to the drawdown and recovery curve differences. 


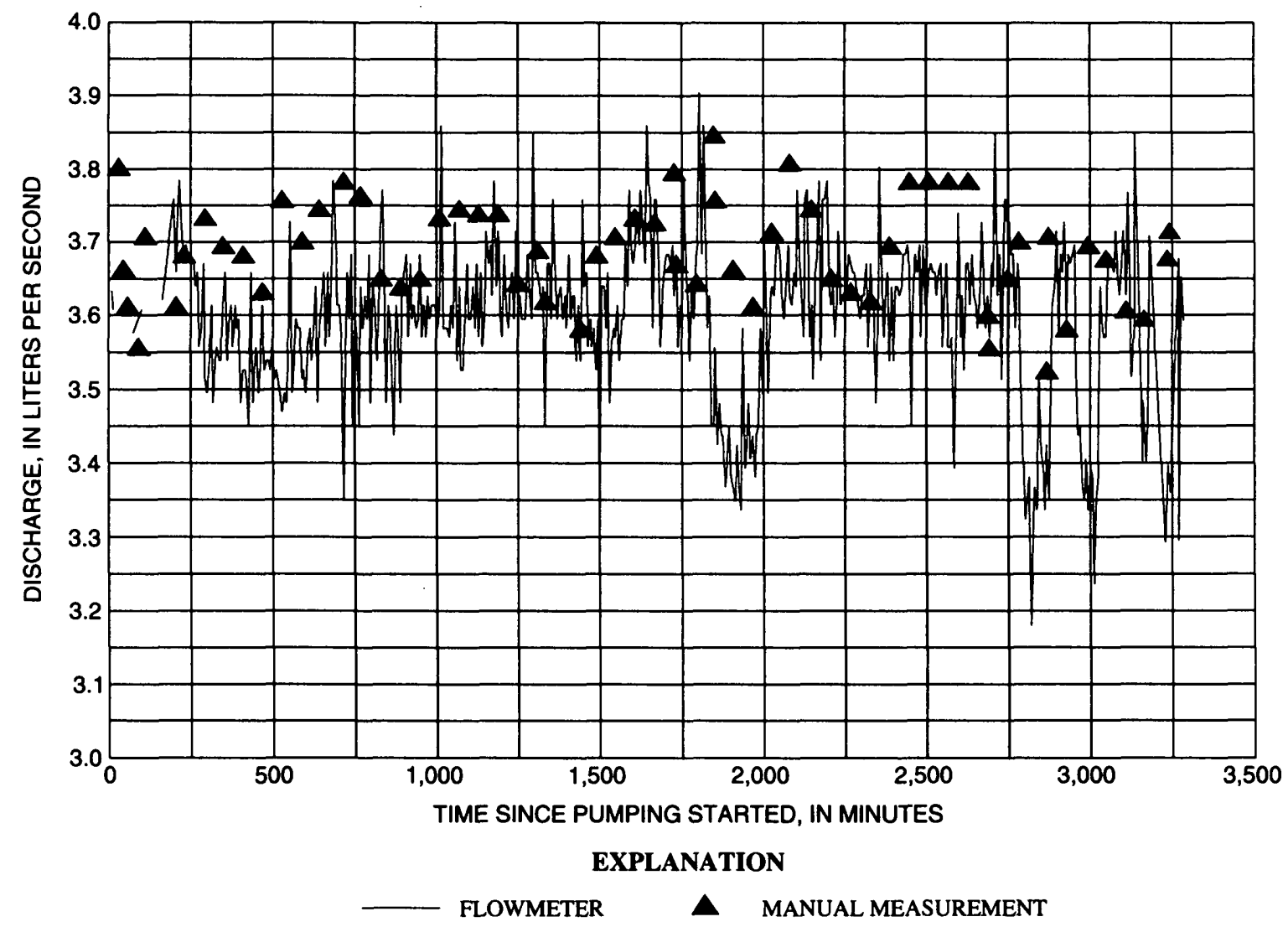

Figure 5. Flowmeter and manual discharge measurements as a function of time during February 1996 aquifer test in borehole USW G-2.

\section{April Aquifer Test}

The second multiple-day aquifer test in borehole USW G-2 was conducted between April 8 and April 25,1996 . The borehole was pumped for 408 hours at a mean discharge rate of $3.60 \mathrm{~L} / \mathrm{s}$, and the maximum drawdown was $37.9 \mathrm{~m}$. The April test was started with $0.26 \mathrm{~m}$ of residual drawdown, even though water levels were allowed to recover for 60 days after the February pumping. Water-level recovery was monitored hourly for 236 days after termination of pumping.

Mean discharge and total discharge were calculated on the basis of manual discharge measurements and flowmeter data. Discharge measured manually and by the flowmeter are presented in figure 9 . The electronic flowmeter had signal quality problems during a 32.8-hour portion of the test (fig. 9), and manual discharge measurements were used to estimate the volume pumped while the flowmeter was not functioning properly. Total discharge for the April test was estimated as 5.3 million $\mathrm{L}$.

\section{Analysis and Results}

At equivalent pumping times, the drawdown data and flow conditions during the February and April aquifer tests were similar (fig. 10). Fracture flow probably dominates the drawdown response at early time during the April 1996 test, as illustrated by line 1 in figure 11 and results in a transmissivity estimate of $9.4 \mathrm{~m}^{2} /$ day. A slight decrease in slope of the drawdown curve, between 200 and 1,000 minutes (line 2 in fig. 11), indicates dual-porosity flow or delayed yield and results in a transmissivity estimate of $11 \mathrm{~m}^{2} /$ day.

Extended pumping during the April test confirmed the presence of aquifer boundaries that were indicated during the February test. After about 3,000 minutes of pumping, the slope of the drawdown curve more than doubles (line 3 in fig. 11) and results in a transmissivity estimate of $3.9 \mathrm{~m}^{2} /$ day. The slope of the drawdown curve increases by about a factor of 4 (relative to the slope of line 1) after about 10,000 minutes (line 4 in fig. 11 ) and results in a transmissivity estimate of $2.3 \mathrm{~m}^{2} /$ day. The increases in rate 


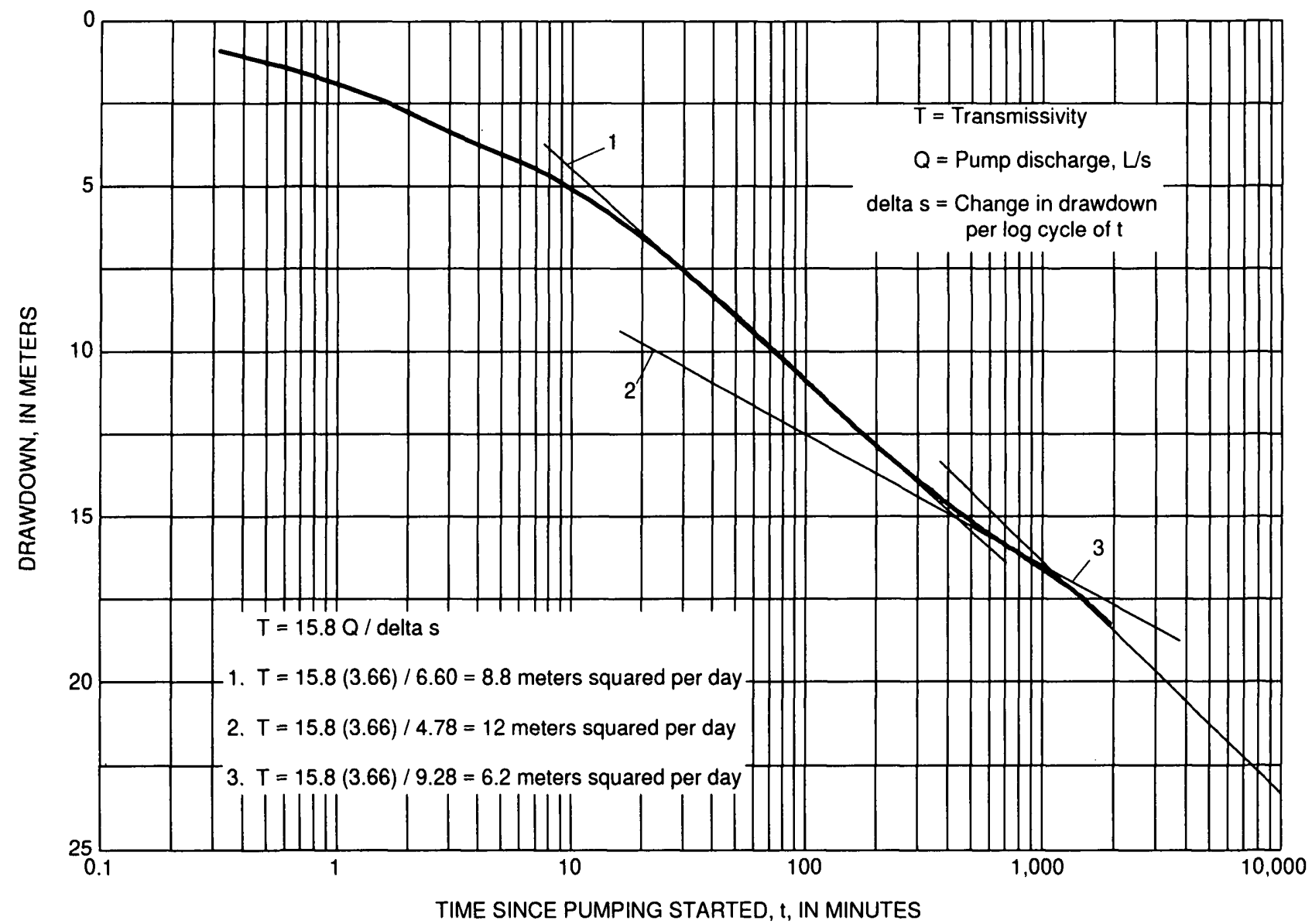

Figure 6. Aquifer-test analysis by straight-line analytical solution for drawdown data during February 1996 test in borehole USW G-2.

of drawdown represented by lines 3 and 4 in figure 11 are interpreted as boundaries. Impermeable boundaries theoretically result in the slope of the drawdown data increasing by a factor of two for the first boundary and by a factor of three for the second boundary (Bruin and Hudson, 1955). In USW G-2 the change in drawdown data slope was greater than expected if aquifer boundaries were reached. The excessive drawdown after reaching the apparent aquifer boundaries may indicate that additional factors, such as perched water, were influencing the response. When the cone of depression reaches the edge of a limited perched water body, the source of water to the borehole would be diminished and the rate of drawdown would increase. A combination of factors probably affected the drawdown response in USW G-2, and it was not possible to definitively determine a single condition that resulted in the observed response.
There are several possible hydrogeologic interpretations for the boundaries observed during pumping. Low-permeability discontinuous fault planes, juxtaposition of lower permeability rock units against the portion of the aquifer system tested, or lithologic changes can function as hydrologic boundaries. An increase in the rate of drawdown, indicated by a boundary, could also be caused by a less than completely saturated area, indicating the edge of a perched-water body.

Recovery was monitored hourly for 236 days and data presented in figure 12 is from the end of pumping on April 25 to December 17, 1996, when the data-acquisition system was removed from the borehole. Three straight-line segments were identified in the recovery. Early-time recovery, indicated by line 1 in figure 12 resulted in a transmissivity estimate of $10 \mathrm{~m}^{2} /$ day. Late-time recovery data, represented by lines 2 and 3 in figure 12, are affected by boundaries, 


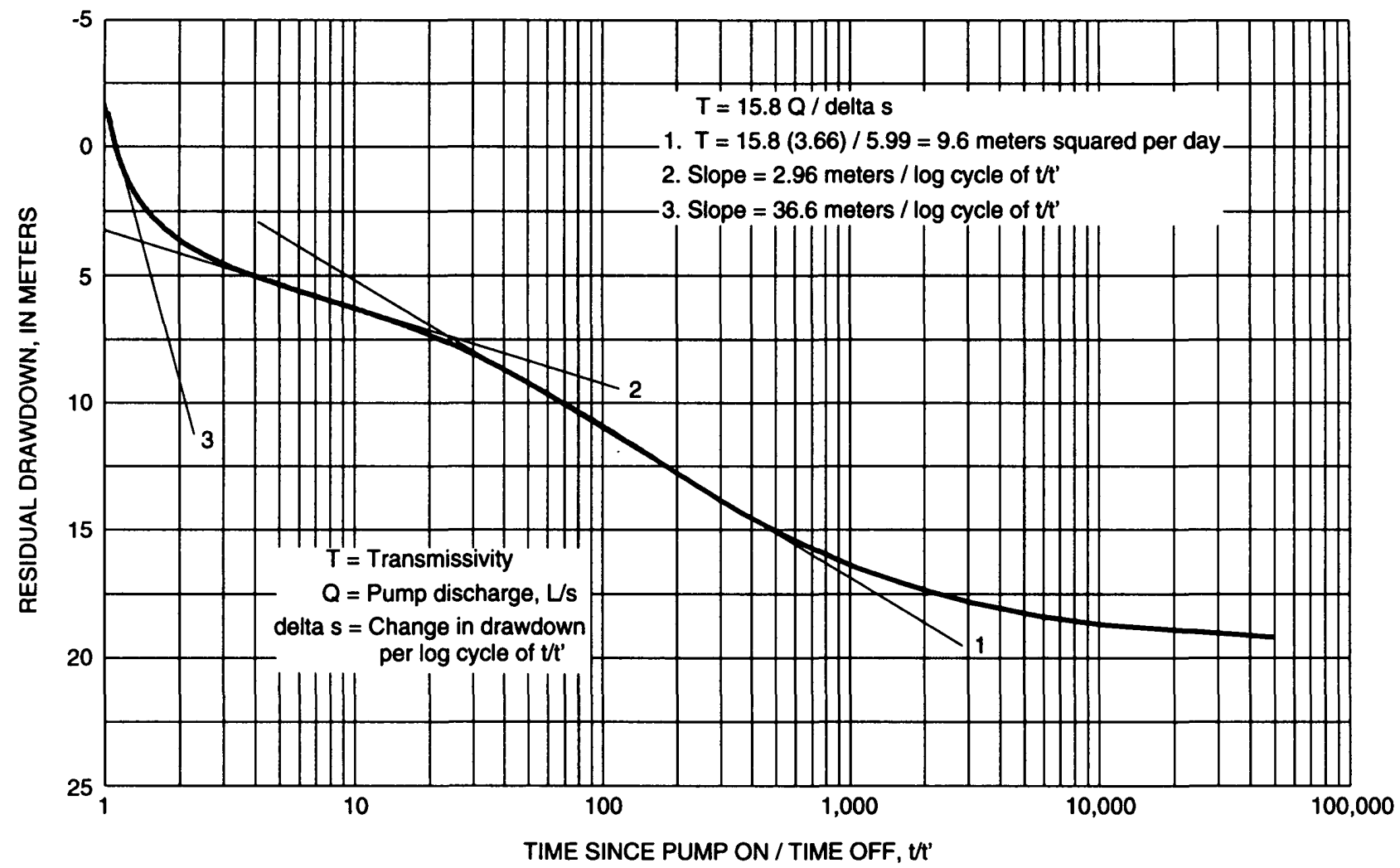

Figure 7. Aquifer-test analysis by straight-line analytical solution for recovery data from February 1996 test in borehole USW G-2.

so transmissivity is not estimated for those data. The April aquifer-test recovery data are illustrated relative to the water-level trend in figure 13.

A summary of transmissivity estimates obtained during testing is provided in table 4 . Generally consistent transmissivity estimates were obtained from the February and April early-time data that represent predominantly fracture-flow conditions. The earlytime transmissivity estimates range from 8.8 to $10 \mathrm{~m}^{2} /$ day, with the April test estimates being slightly higher than the February test estimates. The higher transmissivity estimates from the April test may indicate that fractures were developed during the February pumping. The mean transmissivity for early-time data of $9.4 \mathrm{~m}^{2} /$ day is the most representative estimate for the aquifer system tested in USW G-2. Dual-porosity and boundary-affected transmissivity estimates are probably not representative of the aquifer system under nonpumping conditions.

\section{CONCEPTUAL MODELS}

The substantial increase in water levels to the north of Yucca Mountain, referred to as the large hydraulic gradient, is a significant hydrologic feature. Since the large hydraulic gradient is defined, in part, by the undisturbed water level in USW G-2, data from this borehole can contribute to the understanding of this feature.

Large-scale conceptual models have been proposed to explain the large hydraulic gradient. Two scenarios related to buried geologic features have been used by Fridrich and others (1994) to explain the large hydraulic gradient. The first scenario indicates that a north-bounding fault of a buried graben may provide a permeable pathway, or drain, that allows flow from the tuff aquifer north of the large hydraulic gradient to be captured by the deep carbonate aquifer. The second scenario indicates that a north-bounding fault of a buried graben is the effective northern limit of the tuff 


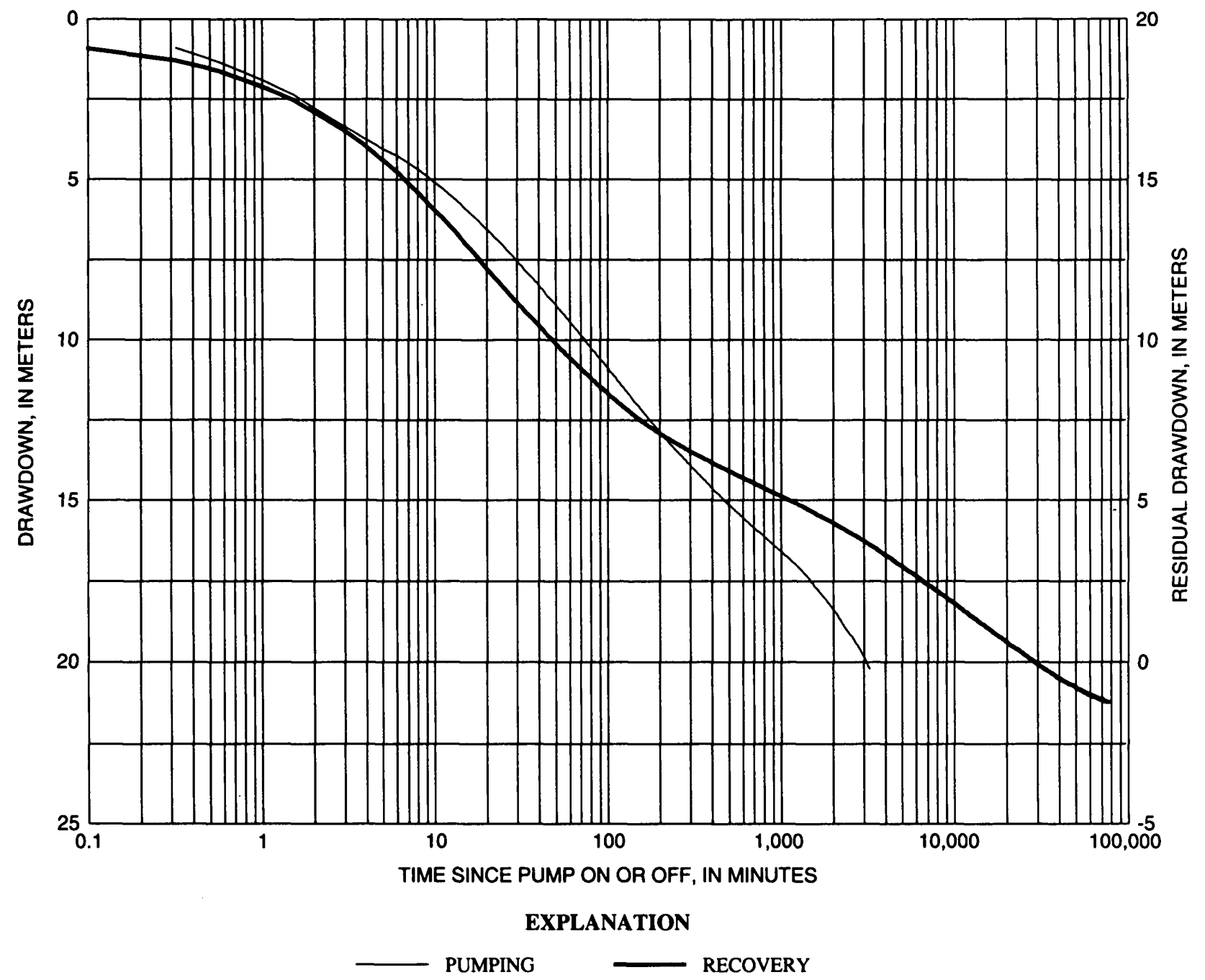

Figure 8. Drawdown and recovery data from the February 1996 aquifer test in borehole USW G-2.

aquifer under Yucca Mountain. The permeability of the tuff north of the fault may have been diminished by hydrothermal alteration. The large hydraulic gradient represents the area where the small southward flow of water through the northern altered volcanic rocks abruptly drops in the tuff aquifer (Fridrich and others, 1994). Czarnecki and others (1994) suggest that thermal alteration in the rocks beneath the Calico Hills Formation produced a series of stepped lowpermeability surfaces that accounts for the large hydraulic gradient.
On the basis of aquifer tests described in this report, two small-scale conceptual models are proposed for the hydrologic system within the large hydraulic gradient area: (1) perched water in the vicinity of borehole USW G-2 may be affecting the observed water level, and the large-hydraulic gradient therefore is not properly defined by the observed water level; (2) the aquifer system intersected by USW G-2 is compartmentalized by low-permeability boundaries, which causes water levels to rise because water accumulates faster than it flows to the south. 
Table 4. Summary of transmissivity estimates obtained from the February and April 1996 aquifer tests in borehole USW G-2

[ $\mathrm{m}^{2} /$ day, meters squared per day]

\begin{tabular}{llllc}
\hline Test period & Data analyzed & Relative time & $\begin{array}{c}\text { Dominant flow } \\
\text { condition }\end{array}$ & $\begin{array}{c}\text { Transmissivity } \\
\left.\text { ( } \mathbf{m}^{2} / \text { day }\right)\end{array}$ \\
\hline February & drawdown & early & fracture & 8.8 \\
April & drawdown & early & fracture & 9.4 \\
February & recovery & early & fracture & 9.6 \\
April & recovery & early & fracture & 10 \\
February & drawdown & middle & dual porosity & 12 \\
April & drawdown & middle & dual porosity & 11 \\
February & drawdown & late & boundary affected & 6.2 \\
April & drawdown & late & boundary affected & 3.9 \\
April & drawdown & late & boundary affected & 2.3 \\
\hline
\end{tabular}

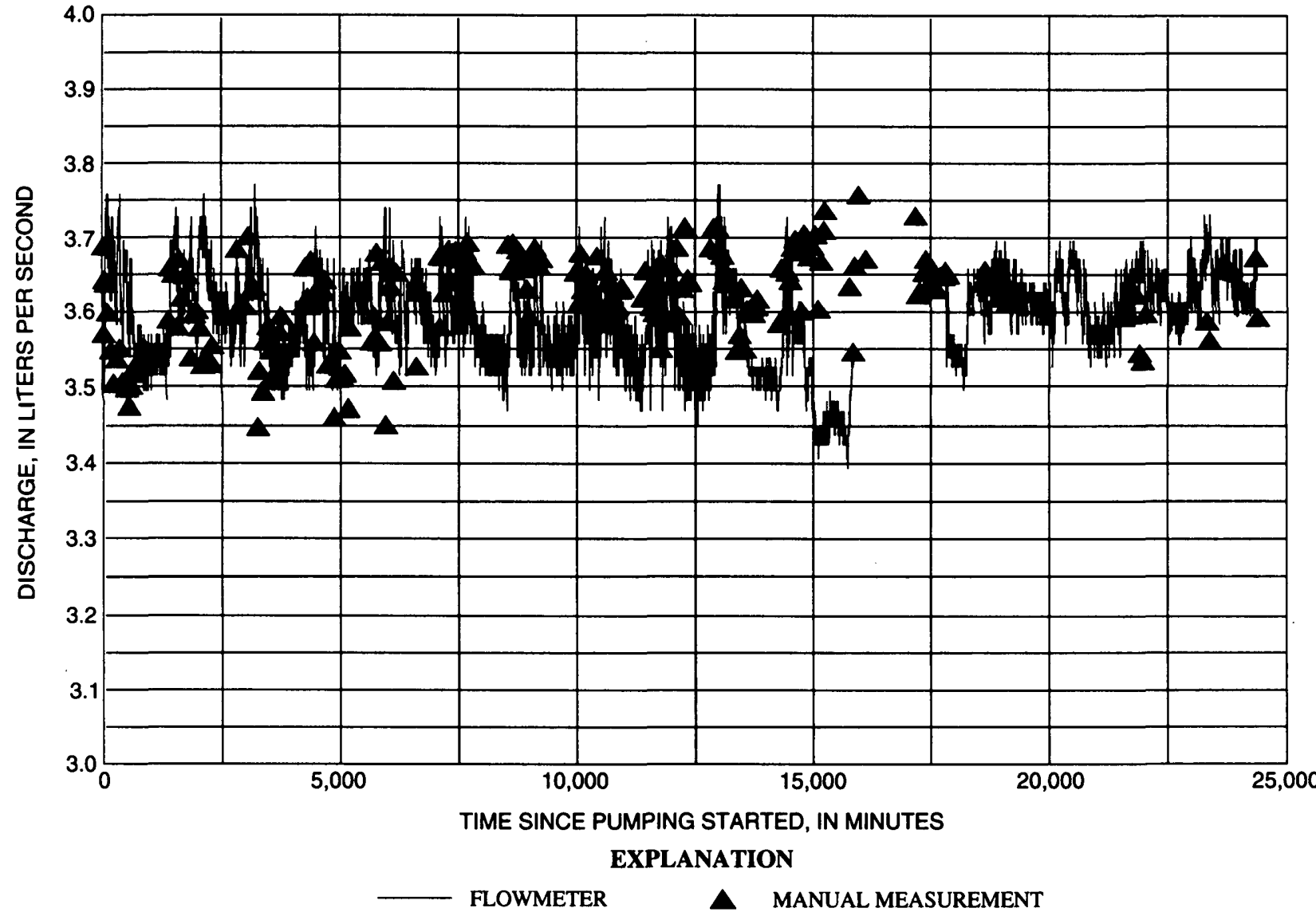

Figure 9. Flowmeter and manual discharge measurements as a function of time during the April 1996 aquifer test in borehole USW G-2. 


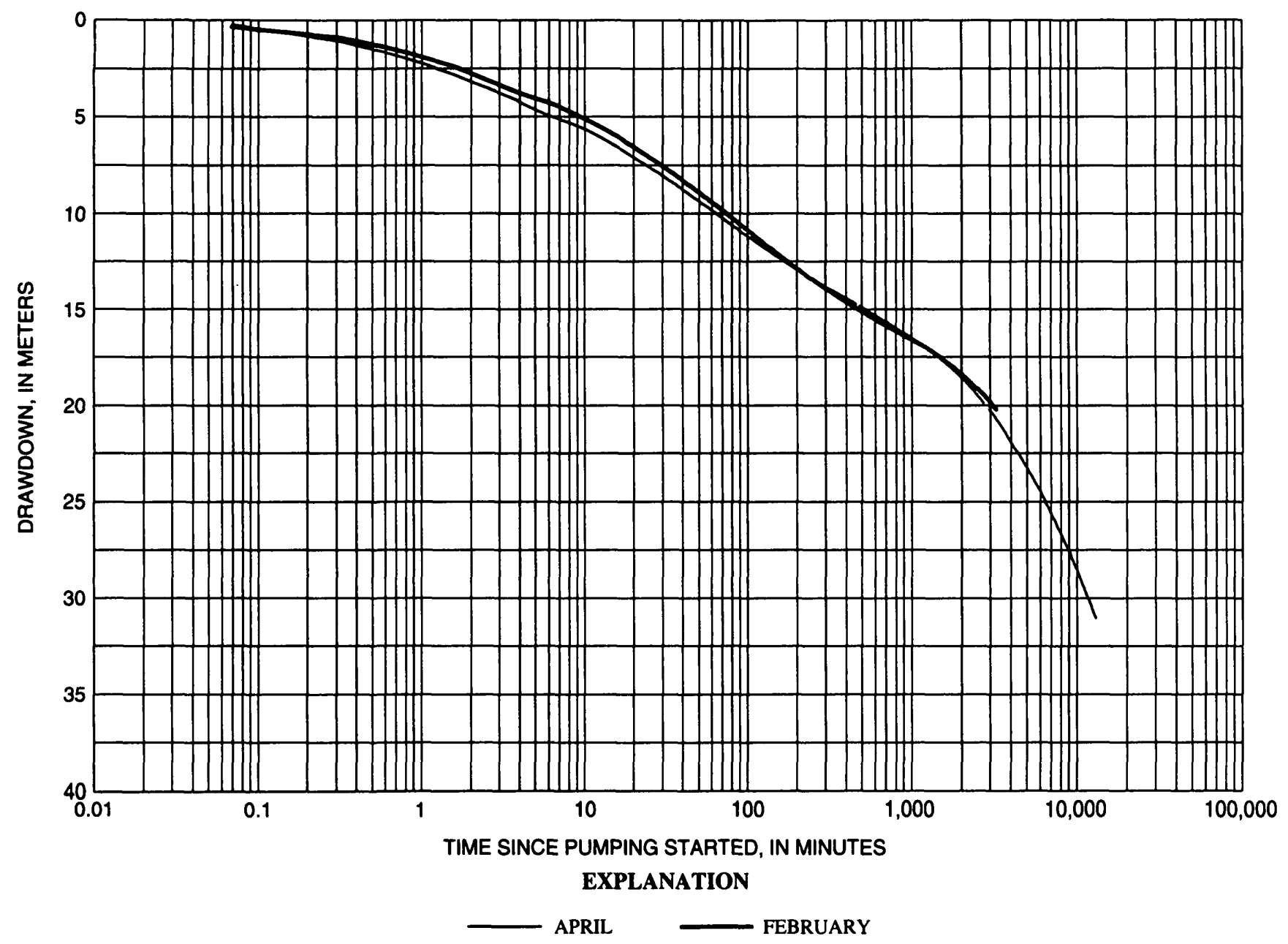

Figure 10. Drawdown data for the February and April 1996 aquifer tests in borehole USW G-2.

\section{Perched Water}

There are several pieces of information from the aquifer tests in USW G-2 that indicate the possibility of perched water. The difference between the undisturbed water level and the observed water level after pumping has ended is termed "residual drawdown." Persistent residual drawdown may indicate that a perched water body has been partially dewatered. A regional aquifer system is expected to return to prepumping levels in about the same time that it was pumped. Water levels in USW G-2, however, had not returned to prepumping levels when hourly monitoring was terminated 236 days after pumping was stopped. There was about $0.5 \mathrm{~m}$ of residual drawdown when the data-acquisition system was removed from the borehole on December 17, 1996. The hourly monitored period of water-level recovery was more than 10 times longer than the duration of pumping. This indi- cates that the water body that was pumped was partially dewatered as a result of pumping more than 6 million L of water between October 1995 and April 1996.

Water-level data accuracy is sufficient to validate the observed residual drawdown. Water levels were measured by a submersible pressure transducer accurate to $\pm 0.036 \mathrm{~m}$. On December 17, 1996, when the pressure transducer was removed from the borehole, the transducer water level was within $0.01 \mathrm{~m}$ of the water level measured by a calibrated steel tape. This indicates that the measured residual drawdown accurately represents the water level in the aquifer system at borehole USW G-2.

In contrast to the observed recovery response in USW G-2, there are several boreholes that are located south of the large hydraulic gradient and that monitor the regional aquifer system; these boreholes have been extensively pumped, and the water levels recovered 


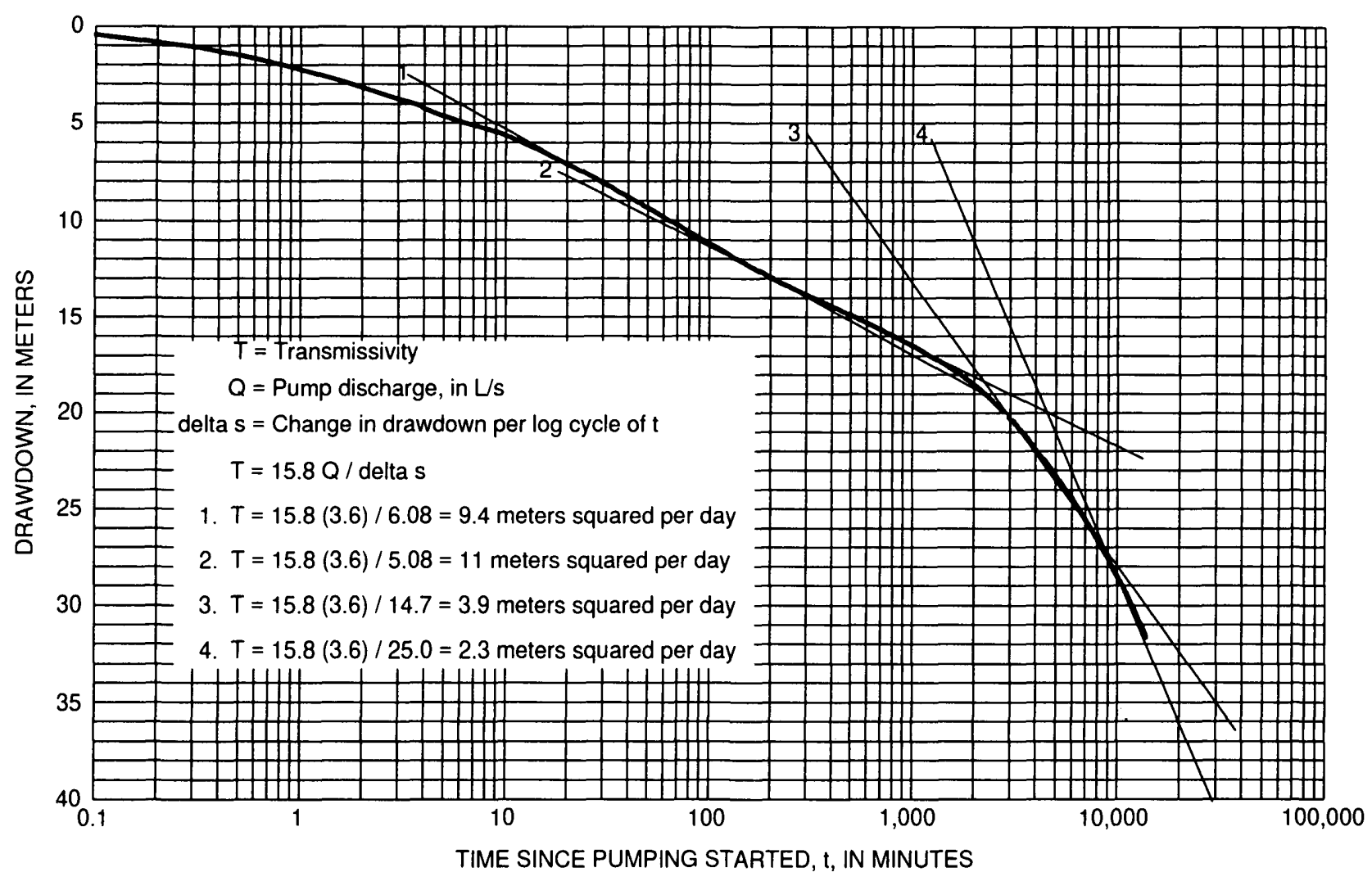

Figure 11. Aquifer-test analysis by straight-line analytical solution for drawdown data during the April 1996 test in borehole USW G-2.

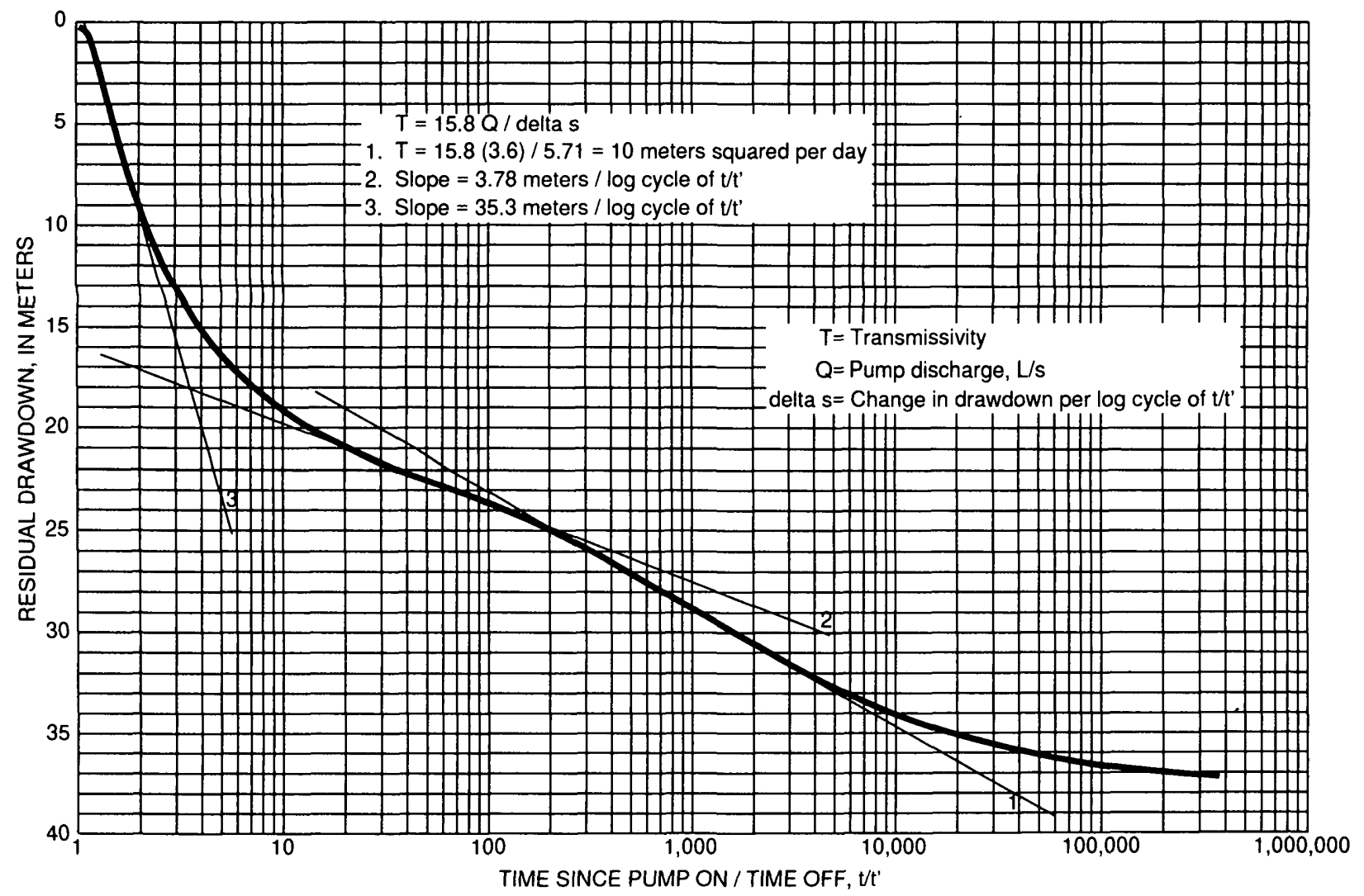

Figure 12. Aquifer-test analysis by straight-line analytical method for recovery data from the April 1996 test in borehole USW G-2. 


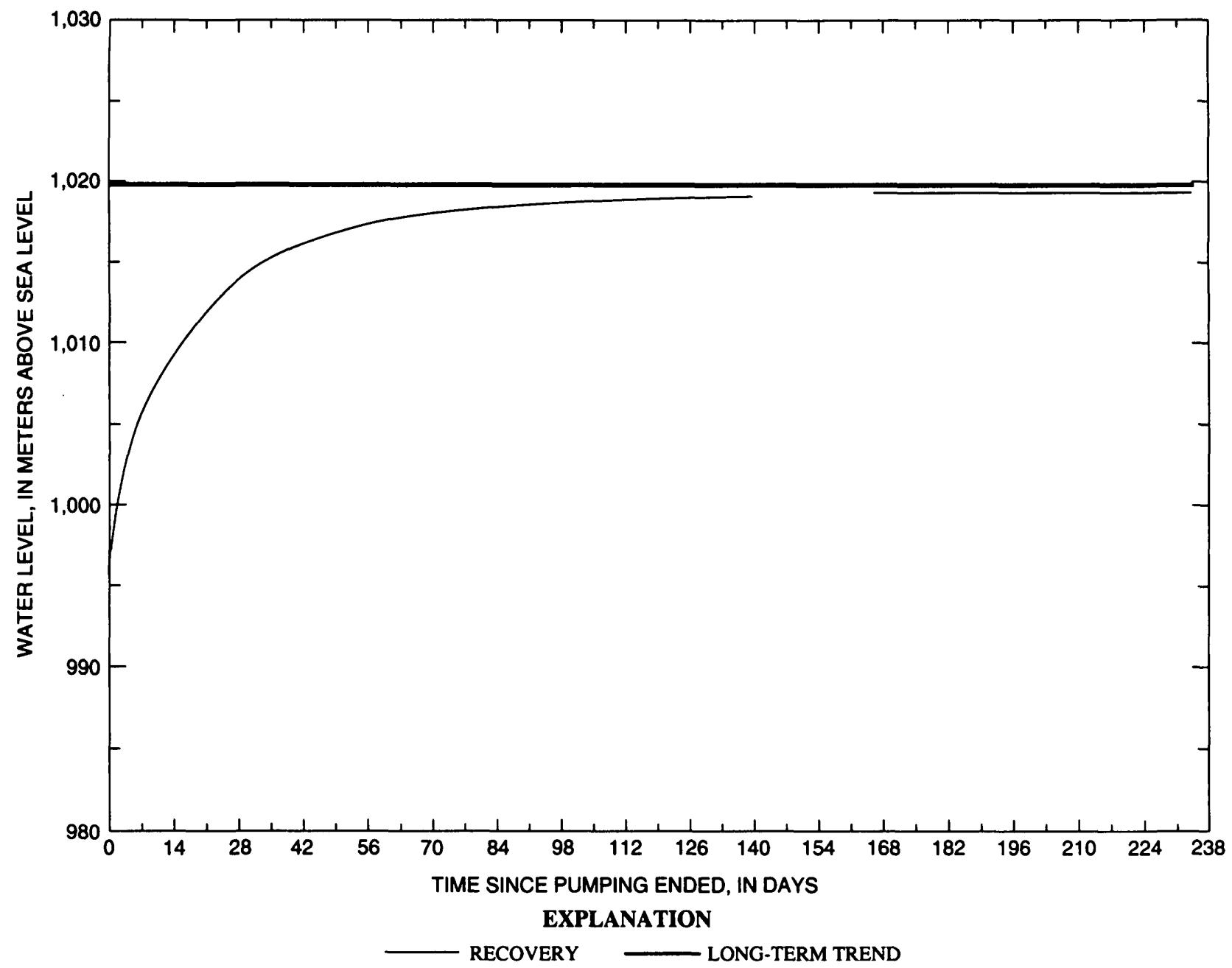

Figure 13. April 1996 aquifer-test recovery data and water-level trend in borehole USW G-2.

within a reasonable time (Craig and Reed, 1991; Craig and Robison, 1984; Moench, 1984; Rush and others, 1984). A perched water zone, however, was pumped in borehole USW SD-7, and the long-term water-level recovery was similar to that observed in USW G-2 (O'Brien, 1997).

Water levels in borehole USW G-2 declined nearly 12 m between 1981 , when USW G-2 was completed, and 1996 (table 1 and fig. 2). This indicates that a perched layer was penetrated during drilling and has allowed water to drain through the borehole. An alternate explanation for the downward water-level trend in USW G-2 is that the borehole is reaching equilibrium as a composite water level. This implies that the hydraulic head decreases with depth, which is consistent with conditions in a recharge area. Video logs, however, show water dripping down the borehole walls above the current water level (J.B.
Czarnecki, U.S. Geological Survey, oral commun., 1996), which also indicates that the borehole is functioning as a drain. Downward flow observed in temperature logs (J.H. Sass, U.S. Geological Survey, written commun., 1994) and flow surveys (F.L. Paillet, U.S. Geological Survey, written commun., 1994) indicates that cool perched water may be flowing into the borehole and exiting through a deeper transmissive zone.

\section{Compartmentalized Flow System}

The slow rate of water-level recovery in USW G-2 also could be caused by pumping water from a compartmentalized flow system. Compartmentalized flow in the Topopah Spring Tuff of southern Nevada has been suggested by Young (1972) and Winograd 
and Thordarson (1975). Young (1972) reports that the Topopah Spring Tuff occurs in a graben with fault boundaries on the east and west sides in the vicinity of Fortymile Wash. Water-level recovery after pumping in borehole USW SD-7 indicated that this type of compartmentalized flow also occurs to the west of Fortymile Wash (O'Brien, 1997). Although no surface faults have been mapped near USW G-2, discontinuous boundaries could form a graben-type structural setting near borehole USW G-2. The low-permeability boundaries indicated during pumping could represent the edges of a graben-type block. This conceptual model is similar to the buried graben structure proposed by Fridrich and others (1994), but on a smaller scale.

Dewatering of the aquifer-system block that is intersected by borehole USW G-2 would create a hydraulic-head difference with water isolated from the borehole by low-permeability boundaries (fig. 14). Water-level recovery in the borehole block would continue until hydraulic-head equilibrium was established with the surrounding blocks. If this conceptual model is correct and a small portion of the entire water body was partially dewatered, then the water levels would be expected to return slowly to prepumping levels.

The water in this potentially compartmentalized flow system could be locally perched water or regional ground water. The observed response due to the cone of depression intersecting low-permeability boundaries would be the same regardless of the water origin. Detailed water-chemistry analysis is needed to distinguish perched water from regional ground water in USW G-2. This type of analysis is beyond the scope of this report.

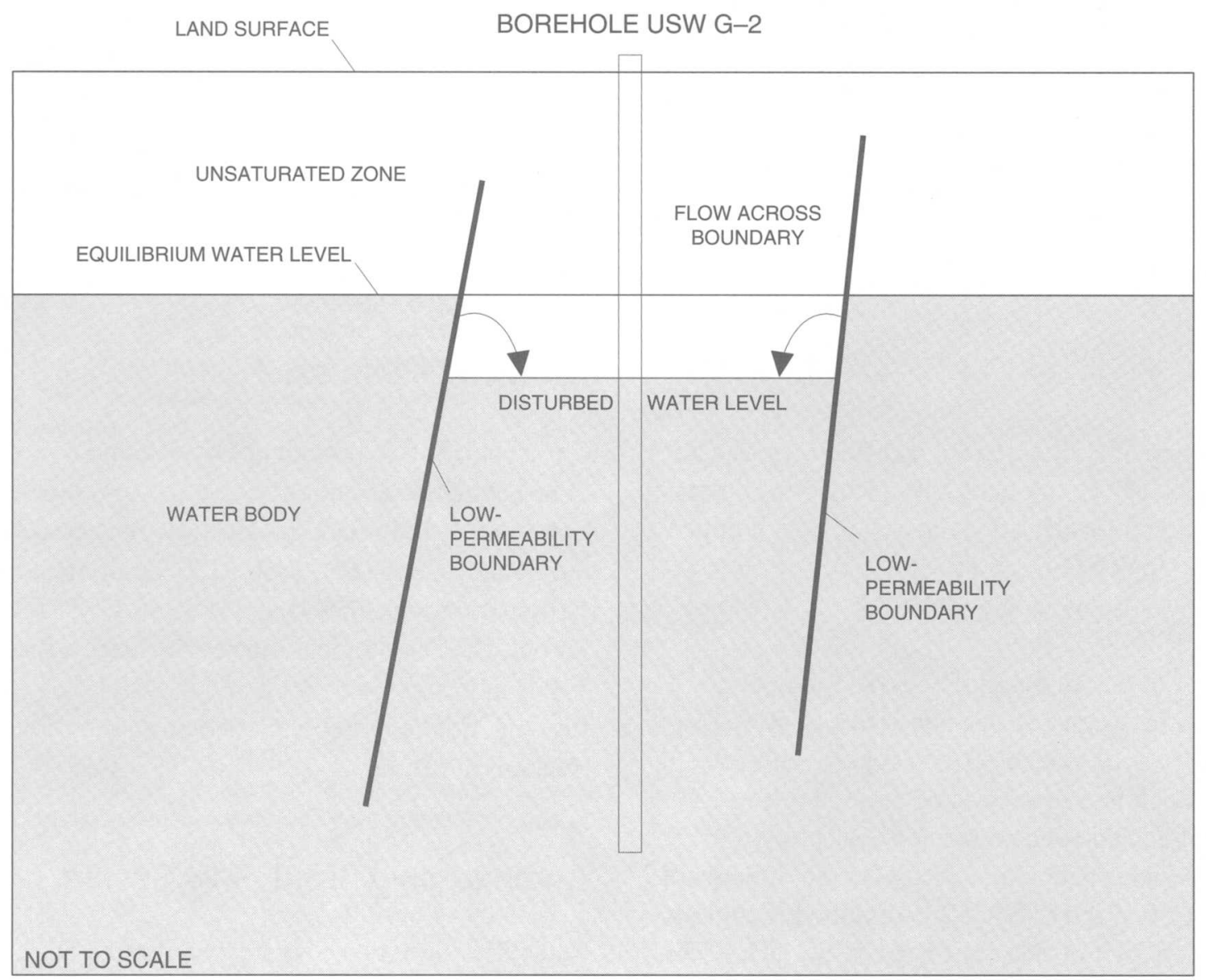

Figure 14. Schematic cross section of possible compartmentalized flow system intersected by borehole USW G-2. 


\section{SUMMARY}

Two aquifer tests were completed in borehole USW G-2 between February and April 1996. The single-borehole tests were conducted to obtain estimates of aquifer transmissivity and to determine if perched water was affecting the observed water level in borehole USW G-2. The February test consisted of 54.9 hours of pumping at a mean discharge rate of $3.66 \mathrm{~L} / \mathrm{s}$. In April, the borehole was pumped for 408 hours at a mean discharge rate of $3.60 \mathrm{~L} / \mathrm{s}$. About 6 million liters of water were pumped from the borehole during the testing. The 259-m thickness of the aquifer system tested consists primarily of the Calico Hills Formation, but the top $3 \mathrm{~m}$ of the water column are within the overlying Topopah Spring Tuff.

Straight-line analytical solutions were used in the analysis of the drawdown and recovery data. Fracture flow, dual-porosity flow, and boundary-affected flow conditions were observed in the drawdown and recovery data. Distances to the aquifer boundaries could not be determined because no observation wells were within the area affected by drawdown. A mean transmissivity of $9.4 \mathrm{~m}^{2} /$ day obtained from the earlytime drawdown and recovery data is the most representative estimate for the aquifer system tested in USW G-2. Transmissivity estimates based on the later time data are probably not representative of the aquifer system under nonpumping conditions.

Perched water may be affecting the observed water level in borehole USW G-2, because the water level did not fully recover after 236 days after the aquifer test. Persistent residual drawdown was about $0.5 \mathrm{~m} 236$ days after pumping ended and indicates that perched water within the aquifer system may have been dewatered. The observed residual drawdown is greater than possible measurement errors. The presence of perched water would imply that the large hydraulic gradient near Yucca Mountain may not be accurately defined with the observed water-level altitude in USW G-2. A quantitative assessment of the effect of perched water on the observed water level in borehole USW G-2, however, cannot be made with the available data.

Another explanation for the residual drawdown due to pumping is that the aquifer system intersected by USW G-2 may be compartmentalized by lowpermeability boundaries. Evidence for a hydraulically isolated block includes the boundaries observed during pumping and the slow rate of recovery. The block- forming boundaries could be caused by several factors, including discontinuous fault planes or lithologic changes or both.

\section{REFERENCES CITED}

Bruin, Jack, and Hudson, H.E., Jr., 1955, Selected methods for pumping test analysis: Illinois State Water Survey Report of Investigation, no. 25, $54 \mathrm{p}$.

Cooper, H.H., Jr., and Jacob, C.E., 1946, A generalized graphical method for evaluating formation constants and summarizing well-field history: American Geophysical Union Transactions, v. 27, no. 7, p. 526-534.

Craig, R.W., and Reed, R.L., 1991, Geohydrology of rocks penetrated by test well USW H-6, Yucca Mountain, Nye County, Nevada: U.S. Geological Survey WaterResources Investigations Report 89-4025, 40 p.

Craig, R.W., and Robison, J.H., 1984, Geohydrology of rocks penetrated by test well UE-25 p\#1, Yucca Mountain area, Nye County, Nevada: U.S. Geological Survey Water-Resources Investigations Report 84-4248, 5 p.

Czarnecki, J.B, O'Brien, G.M., Nelson, P.H., Sass, J.H., Bullard, J.W., and Flint, A.L., 1994, Is there perched water under Yucca Mountain in borehole USW G-2?: Abstract in supplement to EOS, American Geophysical Union, p. 249.

Driscoll, F.G., 1986, Groundwater and wells: Saint Paul, Minnesota, Johnson Division, second edition, 1089 p.

Earlougher, R.C., 1977, Advances in well test analysis: Monograph series, v. 5, Society of Petroleum Engineers of American Institute of Mining, Metallurgical, and Petroleum Engineers (AIME), Dallas, 264 p.

Ferris, J.G., Knowles, D.B., Brown, R.H., and Stallman, R.W., 1962, Theory of aquifer tests: U.S. Geological Survey Water-Supply Paper 1536-E, p. 69-174.

Freeze, R.A., and Cherry, J.A., 1979, Groundwater: Englewood Cliffs, N.J., Prentice-Hall, Inc., 604 p.

Fridrich, C.J., Dudley, W.W., Jr., and Stuckless, J.S., 1994, Hydrogeologic analysis of the saturated-zone groundwater system, under Yucca Mountain, Nevada: Journal of Hydrology, v. 154, p. 133-168.

Graves, R.P., Tucci, Patrick, and Goemaat, R.L., 1996, Water levels in the Yucca Mountain area, Nevada, 1994: U.S. Geological Survey Open-File Report 95-757, $101 \mathrm{p}$.

Lipman, P.W., Christiansen, R.L., and O'Connor, J.T., 1966, A compositionally zoned ash-flow sheet in southern Nevada: U.S. Geological Survey Professional Paper 524-F, p. F1-F47. 
Lohman, S.W., 1963, Method for determination of the coefficient of storage from straight-line plots without extrapolation: U.S. Geological Survey Water-Supply Paper 1545-C, p. 33-37.

Lohman, S.W., 1979, Ground-water hydraulics: U.S. Geological Survey Professional Paper 708, 70 p.

Luckey, R.R., Tucci, Patrick, Faunt, Claudia, Ervin, E.M., Steinkampf, W.C., D'Agnese, F.A., and Patterson, G.L., 1996, Status of understanding of the saturatedzone ground-water flow system at Yucca Mountain, Nevada, as of 1995: U.S. Geological Survey WaterResources Investigations Report 96-4077, 7 p.

Maldonado, Florian, and Koether, S.L., 1983, Stratigraphy, structure, and some petrographic features of Tertiary volcanic rocks at the USW G-2 drill hole, Yucca Mountain, Nye County, Nevada: U.S. Geological Survey Open-File Report 83-732, 83 p.

Moench, A.F., 1984, Double-porosity models for a fissured groundwater reservoir with fracture skin: Water Resources Research, v. 20, no. 7, p. 831-846.

Nelson, P.H., Muller, D.C., Schimschal, Ulrich, and Kibler, J.E., 1991, Geophysical logs and core measurements from forty boreholes at Yucca Mountain, Nevada: U.S. Geological Survey Geophysical Investigations Map GP-1001, 64 p.

Nelson, P.H., and Schimschal, Ulrich, 1993, Assessment of geophysical logs from borehole USW G-2, Yucca Mountain, Nevada: U.S Geological Survey Open-File Report 92-572, 34 p.

O'Brien, G.M., 1997, Analysis of aquifer tests conducted in boreholes USW WT-10, UE-25 WT\#12, and USW SD-7, 1995-96, Yucca Mountain, Nevada: U.S. Geological Survey Water-Resources Investigations Report 96-4293, 36 p.

Papadopulos, I.S., and Cooper, H.H., Jr., 1967, Drawdown in a well of large diameter: Water Resources Research, v. 3, p. 241-244.

Robison, J.H., Stephens, D.M., Luckey, R.R., and Baldwin, D.A., 1988, Water levels in periodically measured wells in the Yucca Mountain area, Nevada, 1981-87: U.S. Geological Survey Open-File Report 88-468, $132 \mathrm{p}$.
Rush, F.E., Thordarson, William, and Pyles, D.G., 1984, Geohydrology of test well USW H-1, Yucca Mountain, Nye County, Nevada: U.S. Geological Survey Water-Resources Investigations Report 84-4032, 56 p.

Schafer, D.C., 1978, Casing storage can affect pumping test data: Johnson Drillers' Journal, Third Quarter, Johnson Division, UOP Inc., St. Paul, Minnesota, p. 1-11.

Stock, J.M., Healy, J.H., and Hickman, S.H., 1984, Report on televiewer $\log$ and stress measurements in core hole USW G-2, Nevada Test Site October-November, 1982: U.S. Geological Survey Open-File Report 84-172, 47 p.

Theis, C.V., 1935, The relation between the lowering of the piezometric surface and the rate and duration of discharge of a well using ground-water storage: Transactions of the American Geophysical Union, v. 16, p. 519-524.

Tucci, Patrick, and Burkhardt, D.J., 1995, Potentiometricsurface map, 1993, Yucca Mountain and vicinity, Nevada: U.S. Geological Survey Water-Resources Investigations Report 95-4149, 15 p.

Tucci, Patrick, Goemaat, R.L., and Burkhardt, D.J., 1996, Water levels in the Yucca Mountain area, Nevada, 1993: U.S. Geological Survey Open-File Report 95-159, $94 \mathrm{p}$.

Weeks, E.P., 1978, Aquifer tests - The state of the art in hydrology: Proceedings, Invitational Well-Testing Symposium, Berkeley, Calif., p. 14-23.

Winograd, I.J., and Thordarson, William, 1975, Hydrogeologic and hydrochemical framework, south-central Great Basin, Nevada-California, with special reference to the Nevada Test Site: U.S. Geological Survey Professional Paper 712-C, 126 p.

Young, R.A., 1972, Water supply for the nuclear rocket development station at the U.S. Atomic Energy Commission's Nevada Test Site: U.S. Geological Survey Water-Supply Paper 1938, 19 p. 


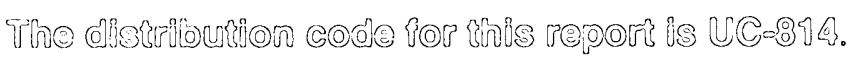


